\title{
Holocene climate variability in north-eastern Italy: potential influence of the NAO and solar activity recorded by speleothem data
}

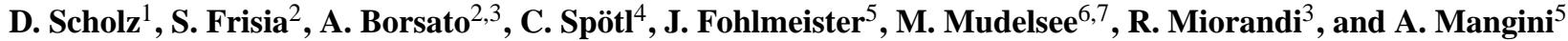 \\ ${ }^{1}$ Institute for Geosciences, Johannes-Gutenberg-Universität Mainz, Becherweg 21, 55128 Mainz, Germany \\ ${ }^{2}$ School of Environmental and Life Sciences, University of Newcastle, Callaghan 2308 NSW, Australia \\ ${ }^{3}$ Museo delle Scienze, via Calepina 14, 38122 Trento, Italy \\ ${ }^{4}$ Institut für Geologie und Paläontologie, Leopold-Franzens-Universität, Innrain 52, 6020 Innsbruck, Austria \\ ${ }^{5}$ Heidelberger Akademie der Wissenschaften, Im Neuenheimer Feld 229, 69120 Heidelberg, Germany \\ ${ }^{6}$ Climate Risk Analysis, Schneiderberg 26, 30167 Hannover, Germany \\ ${ }^{7}$ Alfred Wegener Institute for Polar and Marine Research, Climate Science Division, Bussestrasse 24, \\ 27570 Bremerhaven, Germany
}

Correspondence to: D. Scholz (scholzd@uni-mainz.de)

Received: 27 January 2012 - Published in Clim. Past Discuss.: 23 March 2012

Revised: 11 July 2012 - Accepted: 20 July 2012 - Published: 27 August 2012

\begin{abstract}
Here we present high-resolution stable isotope and lamina thickness profiles as well as radiocarbon data for the Holocene stalagmite ER 76 from Grotta di Ernesto (northeastern Italy), which was dated by combined U-series dating and lamina counting. ER 76 grew between $8 \mathrm{ka}$ (thousands of years before $2000 \mathrm{AD}$ ) and today, with a hiatus from 2.6 to $0.4 \mathrm{ka}$.

Data from nine meteorological stations in Trentino show a significant influence of the North Atlantic Oscillation (NAO) on winter temperature and precipitation in the cave region. Spectral analysis of the stable isotope signals of ER 76 reveals significant peaks at periods of 110, 60-70, 40-50, 3237 and around 25 a. Except for the cycle between 32 and 37 a all periodicities have corresponding peaks in power spectra of solar variability, and the 25-a cycle may correspond to NAO variability. This suggests that climate variability in northern Italy was influenced by both solar activity and the NAO during the Holocene.

Six periods of warm winter climate in the cave region were identified. These are centred at 7.9, 7.4, 6.5, 5.5, 4.9 and $3.7 \mathrm{ka}$, and their duration ranges from 100 to $400 \mathrm{a}$. The two oldest warm phases coincide with the deposition of sapropel S1 in the Mediterranean Sea indicating that the climate in the cave region was influenced by this prominent pluvial phase in the Mediterranean area. For the younger warm phases it is difficult to establish a supra-regional climate pattern, and
\end{abstract}

some of them may, thus, reflect regional climate variability. This highlights the complexity of regional and supra-regional scale Holocene climate patterns.

\section{Introduction}

Based on isotopic records from Greenland ice cores (e.g., North Greenland Ice Core Project members, 2004), the Holocene appears as a relatively stable climatic period compared to the large climate fluctuations during the last glacial period. However, an examination of globally distributed high-resolution climate proxy records shows that Holocene climate variations were larger and more frequent than has been commonly recognised (Mayewski et al., 2004; Wanner et al., 2008, 2011). The complexity of Holocene climate patterns in central and southern Europe is, for instance, well exemplified by the work of Davis et al. (2003), Magny et al. $(2003,2006)$ and Drysdale et al. (2006). On the basis of lake-level fluctuations, Magny et al. (2003) hypothesised that during Holocene cooling phases, marked by icerafted debris (IRD) events in the North Atlantic (Bond et al., 2001), more humid conditions prevailed in European midlatitudes (i.e., between $50^{\circ}$ and $43^{\circ} \mathrm{N}$ ) while at the same time, the regions north and south of this area experienced drier conditions. Drysdale et al. (2006) suggested "a lack 
of consistency in the way specific regions respond to IRD events" by comparing the oxygen isotope, trace element and organic fluorescence record of a Holocene flowstone from central-western Italy with marine sediment cores from the North Atlantic and speleothems from the Middle East. Finally, Magny et al. (2006) identified a complex regional-scale pattern between 5.6 and $5.3 \mathrm{ka}$ (thousands of years before 2000 AD) with cooler and wetter conditions in central Europe, cold conditions in eastern Europe and dry conditions in southern Europe. The climate of mountainous regions, such as the Alps and the Apennines is, furthermore, influenced by mesoscale systems, orography and cyclonic disturbances. The complexity of all these phenomena is likely to be reflected in climate proxy records and may even be predominant over global climate signals.

Present-day climate conditions during winter months in both central Europe and the Italian peninsula are strongly influenced by the variability of the North Atlantic pressure field, known as the North Atlantic Oscillation (NAO), because the Azorean high and Icelandic low pressure cells direct the atmospheric flow either eastward into the Mediterranean area or north-eastward to northern Europe according to their strengths and positions (Wanner et al., 2001). Alpine north-eastern Italy is located in a key position between central Europe and the Italian peninsula (Fig. 1) since both the Alps and the Apennines represent orographic barriers for moisture transport from the North Atlantic. Furthermore, the climate of the region is influenced by cold and dry winds from eastern Europe. Thus, north-eastern Italy represents an interesting area for paleoclimatic studies (Baroni et al., 2006), which potentially provide information for the reconstruction of past circulation patterns in response to external and internal climate forcing. However, whereas Holocene climate variability has been intensively studied both in the Alps (e.g., Nicolussi and Patzelt, 2000; Holzhauser et al., 2005; Mangini et al., 2005; Magny, 2004; Joerin et al., 2006) and the Mediterranean region (e.g., Bar-Matthews et al., 2000; Emeis et al., 2000; Frisia et al., 2006; Ariztegui et al., 2000; Magny et al., 2007; Drysdale et al., 2006; Roberts et al., 2008), long, uninterrupted high-resolution paleoclimate records from north-eastern Italy for the Holocene are still sparse (exceptions include those presented by Frisia et al., 2003, 2005; Baroni et al., 2001, 2006; McDermott et al., 1999).

Here we present a high-resolution Holocene proxy record for the annually laminated stalagmite ER 76 from Grotta di Ernesto cave. Decade-long, extensive monitoring of cave physics and chemical parameters has revealed that stalagmite growth inside this cave is modulated by cave ventilation in response to the seasonal difference between cave and surface temperature (Frisia et al., 2011). Thus, the systematics of calcite growth are exceptionally well understood (Miorandi et al., 2010), which enabled the calculation of surface temperature variability for the past $\sim 500$ a on the basis of annual

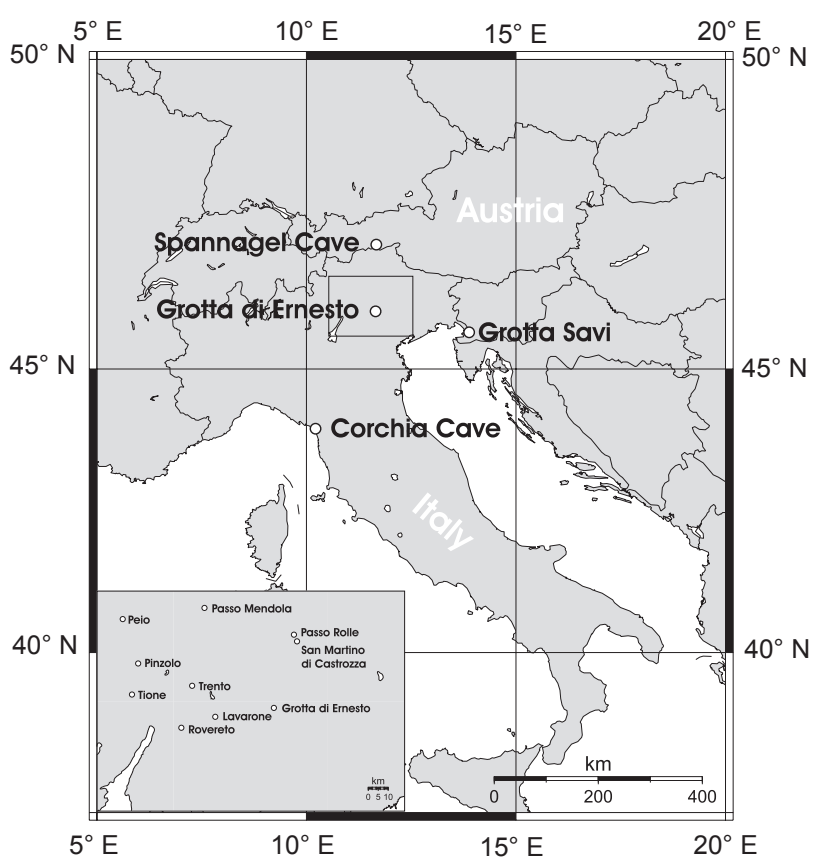

Fig. 1. Map showing the location of Grotta di Ernesto in northeastern Italy south of the Alpine watershed. Also shown are the locations of Spannagel cave (Austrian Alps), Savi Cave (near Trieste) and Corchia cave (Alpi Apuane, Italy). The rectangle denotes the position of the enlarged section, which shows the locations of the nine weather stations in Trentino used to quantify the influence of the NAO (see text for details).

lamina thickness changes in three stalagmites (Smith et al., 2006; Frisia et al., 2003).

The monitoring programme has revealed a complex interplay of various processes influencing the proxy signals recorded in speleothems from the Grotta di Ernesto. As a consequence, the only Holocene speleothem stable isotope record from the cave published so far is the relatively lowresolution record of stalagmite ER 76 (McDermott et al., 1999). Based on our improved understanding of the underlying cave processes, we reassess stalagmite ER 76 here and present a new high-resolution stable isotope record and a novel age model based on new U/Th- and lamina-thickness data. In addition, we determined several radiocarbon ages enabling the calculation of the dead carbon fraction (dcf).

\section{Study site, samples and methods}

\subsection{Geographic setting and local climate}

Grotta di Ernesto (Trentino, NE Italy, $45^{\circ} 58^{\prime} \mathrm{N}, 11^{\circ} 39^{\prime} \mathrm{E}$ ) is located at $1167 \mathrm{~m}$ above sea level at the margin between the Mediterranean and the Alps (Fig. 1). It is, therefore, a key site to gain insight into the mechanisms controlling European climate phenomena. The cave location on the north-facing cliff 
Table 1. Results of U-series dating.

\begin{tabular}{lrrrrrrr}
\hline Sample & $\begin{array}{r}\text { Distance } \\
\text { from top } \\
{[\mathrm{mm}]}\end{array}$ & $\begin{array}{r}{ }^{238} \mathrm{U} \\
{[\mathrm{ppb}]}\end{array}$ & $\left({ }^{234} \mathrm{U} /{ }^{238} \mathrm{U}\right)$ & $\left({ }^{230} \mathrm{Th} /{ }^{238} \mathrm{U}\right)$ & $\left({ }^{230} \mathrm{Th} /{ }^{232} \mathrm{Th}\right)$ & Age corrected [ka] & Age uncorrected [ka] \\
\hline ER76-3 & 30.0 & 27.2 & $2.096 \pm 0.006$ & $0.043 \pm 0.002$ & $100.3 \pm 3.7$ & $2.27 \pm 0.08$ & $2.29 \pm 0.08$ \\
ER76-8.25 & 82.5 & 38.4 & $2.165 \pm 0.008$ & $0.074 \pm 0.005$ & $13.4 \pm 0.8$ & $3.79 \pm 0.25$ & $4.03 \pm 0.25$ \\
ER76-16 & 160.0 & 34.7 & $2.128 \pm 0.008$ & $0.087 \pm 0.003$ & $147.6 \pm 4.3$ & $4.55 \pm 0.13$ & $4.57 \pm 0.13$ \\
ER76-17.5 & 175.0 & 34.0 & $2.075 \pm 0.012$ & $0.095 \pm 0.003$ & $88.7 \pm 3.3$ & $5.10 \pm 0.19$ & $5.14 \pm 0.19$ \\
ER76-20.5 & 205.0 & 38.3 & $2.049 \pm 0.006$ & $0.101 \pm 0.002$ & $17.0 \pm 0.3$ & $5.51 \pm 0.10$ & $5.77 \pm 0.10$ \\
ER76-25.5 & 255.0 & 22.8 & $1.801 \pm 0.007$ & $0.108 \pm 0.003$ & $27.5 \pm 0.7$ & $6.75 \pm 0.18$ & $6.95 \pm 0.18$ \\
ER76-28 & 280.0 & 23.6 & $1.819 \pm 0.006$ & $0.124 \pm 0.006$ & $39.9 \pm 2.0$ & $7.67 \pm 0.36$ & $7.82 \pm 0.36$ \\
ER76-35.5 & 355.0 & 24.2 & $1.783 \pm 0.010$ & $0.125 \pm 0.007$ & $31.1 \pm 1.7$ & $7.92 \pm 0.45$ & $8.13 \pm 0.45$ \\
\hline
\end{tabular}

U-series ages are calculated iteratively using: $\left(\frac{230 \mathrm{Th}}{238 \mathrm{U}}\right)=1-\exp \left(-\lambda_{230} t\right)+\left(\left(\frac{{ }^{234} \mathrm{U}}{238 \mathrm{U}}\right)-1\right) \frac{\lambda_{230}}{\lambda_{230}-\lambda_{234}}\left(1-\exp \left(-\left(\lambda_{230}-\lambda_{234}\right) t\right)\right) \cdot t$ is the age in years, and the $\lambda_{i}$ 's are the corresponding decay constants for ${ }^{230} \mathrm{Th}$ and ${ }^{234} \mathrm{U} . \lambda_{234}=2.8263 \times 10^{-6} \mathrm{a}^{-1} ; \lambda_{230}=9.1577 \times 10^{-6} \mathrm{a}^{-1}$ as reported by Cheng et al. (2000). All activity ratios have been corrected for contamination by detrital ${ }^{238} \mathrm{U},{ }^{234} \mathrm{U}$ and ${ }^{230} \mathrm{Th}$, assuming a silicate source with a ${ }^{232} \mathrm{Th} /{ }^{238} \mathrm{U}$ weight ratio of 3.8 and with ${ }^{230} \mathrm{Th}$, ${ }^{234} \mathrm{U}$ and ${ }^{238} \mathrm{U}$ in secular equilibrium. All errors are quoted at $2 \sigma$-level.

of the Asiago karst plateau (Marcesina-Vezzena-Lavarone) results in a strong seasonal temperature contrast at the surface, with mean monthly air temperatures ranging from $0{ }^{\circ} \mathrm{C}$ during winter to $15^{\circ} \mathrm{C}$ during summer. Annual precipitation at Lavarone, $15 \mathrm{~km}$ to the west of Grotta di Ernesto at the same elevation and on the same plateau (Fig. 1), ranged from 531 to $2268 \mathrm{~mm} \mathrm{a}^{-1}$ between 1921 and 2007, with a mean value of $1289 \mathrm{~mm} \mathrm{a}^{-1}$. The majority of precipitation falls in spring/early summer (May/June) and late autumn (October/November).

Instrumental data from the weather station in Trento (Fig. 1) for the past approximately 180 a show that climate in the region largely reflects that of northern Italy (Rea et al., 2004; Sadler and Bellin, 2004). Lagrangian computation of wind trajectories applied to a large ensemble of precipitation events, which were selected by accounting for the effective recharge at Grotta di Ernesto (Frisia et al., 2003), highlight the important contribution of Mediterranean cyclones to local precipitation and a strong dispersion within 5-days backtrajectories (Bertò et al., 2004).

Spectral analysis of long instrumental series in Trentino suggests an influence of the NAO on winter precipitation (Sadler and Bellin, 2004). Spectral analysis of lamina thickness data from three stalagmites from Grotta di Ernesto also indicates that winter climate in Trentino was modulated by the NAO at least within the past 500 a (Frisia et al., 2003). A recent study of the influence of large-scale atmospheric circulation on climate variability in the Alpine region of Europe showed that the NAO, and especially its Mediterranean component affects precipitation over the southern Alpine region (Efthymiadis et al., 2007). In particular, high-altitude winter temperatures are linked to the NAO. Positive phases of the $\mathrm{NAO}\left(\mathrm{NAO}^{+}\right.$-phases) are associated with drier than normal winters in the south-western Alpine region, whereas negative phases of the $\mathrm{NAO}\left(\mathrm{NAO}^{-}\right.$-phases) are characterised by higher winter precipitation (Efthymiadis et al., 2007). Here we investigate the influence of the NAO at the cave site using precipitation data from Trentino for the last $\sim 85$ a (Sects. 2.3 and 3.1).

\subsection{Cave physics and stalagmite samples}

Grotta di Ernesto is a simple descending gallery with one entrance, today sealed by a solid door. The gallery is developed between $\sim 2$ and $\sim 30 \mathrm{~m}$ below the surface, and this shallow setting is a pre-requisite for the preservation of seasonal climatic signals in speleothems (Fairchild et al., 2007). A decade-long monitoring programme provides the benchmark for the interpretation of the hydrological and physical processes regulating stalagmite growth (Miorandi et al., 2010; Frisia et al., 2011), the development of visible annual growth laminae (Frisia et al., 2000, 2003) and the seasonal variability of trace-element composition (Borsato et al., 2007a).

The mean annual temperature in the cave is remarkably constant at $\sim 6.7^{\circ} \mathrm{C}$ reflecting the mean annual surface air temperature (Frisia et al., 2011). Cave air $p \mathrm{CO}_{2}$ varies seasonally (Frisia et al., 2003) and is modulated by air advection due to the seasonal difference between surface air and cave temperature (Frisia et al., 2011). Cave air $p \mathrm{CO}_{2}$ is lower in winter than during summer, which results in increased degassing of $\mathrm{CO}_{2}$ from dripwater (Fairchild et al., 2007; Frisia, 2011) and, thus, higher calcite precipitation rates during winter (Miorandi et al., 2010).

The $368 \mathrm{~mm}$-long stalagmite ER 76 grew in a passage located about $20 \mathrm{~m}$ below the surface. The drip rate of the stalactite exhibits a base-flow of $\sim 0.02 \mathrm{ml} \mathrm{min}^{-1}$ and reaches up to $\sim 0.7 \mathrm{ml} \mathrm{min}^{-1}$ with a delay of about two months with respect to major and prolonged aquifer recharge (Miorandi et al., 2010). This hydrological behaviour may be related to the reservoir feeding ER 76, which probably receives the overflow from other conduits. Drip water $\delta^{18} \mathrm{O}$ values at the drip site of ER 76 show a decreasing trend from -8.5 to 
$-9.8 \%$ o between 2004 and 2008 and, in general, low variability throughout the year (ca. $0.2-0.4 \%$ ). A seasonal signal reflecting the pattern of the $\delta^{18} \mathrm{O}$ values of precipitation above the cave is not visible. This suggests a relatively long residence time for the water in the aquifer above the ER 76 drip site and a well mixed reservoir. Thus, the growth rate of ER 76 is more sensitive to surface temperature than rainfall, which is probably related to the surface temperature influence on soil $\mathrm{CO}_{2}$ production and the successive phenomenon of degassing (Frisia et al., 2003).

The $440 \mathrm{~mm}$ long stalagmite ER 77 was sampled in a deeper chamber of the same gallery, $\sim 30 \mathrm{~m}$ below the surface. The feeding stalactite shows an almost constant drip rate $\left(\sim 0.2 \mathrm{ml} \mathrm{min}^{-1}\right)$ and low sensitivity to infiltration events or prolonged dry periods (Miorandi et al., 2010). During the last $500 \mathrm{a}$, the growth of this stalagmite was, thus, also modulated by temperature and degassing rather than water availability (Frisia et al., 2003). In the uppermost part of ER 77, the bomb ${ }^{14} \mathrm{C}$ peak has been detected demonstrating that the stalagmite was active when it was sampled (Fohlmeister et al., 2011a).

Whereas the lower and larger portions of both stalagmites consist of porous and milky columnar calcite, compact and translucent columnar calcite is more common in the upper $\sim 15 \mathrm{~mm}$. Both porous and compact columnar calcite shows annual growth laminae (Huang et al., 2001; Frisia et al., 2003), whose annual nature has been demonstrated by Useries ages (Frisia et al., 2003) and confirmed by a semiautomated approach (Meyer et al., 2006). The annual cyclicity is also marked by variations in the concentration of trace elements (Borsato et al., 2007a), with the onset of the hydrological year being characterised by a clear positive peak in the content of Y. McDermott et al. (1999) inferred that the growth of stalagmite ER 76 started approximately $9.1 \mathrm{ka}$ ago on the basis of U-series dating. Frisia et al. (2006), however, subsequently inferred on the basis of annual lamina counting that its growth started at least 600 a later (i.e., at ca. $8.5 \mathrm{ka}$ ) and accordingly revised the age model of McDermott et al. (1999). These previous age models are tested here using new $\mathrm{U}$-series dates.

\subsection{Methods}

The influence of the NAO on winter climate in the cave region was assessed by calculation of the correlation between the winter NAO index (DJF) and the amount of winter precipitation as well as winter temperature (i.e, December, January and February, DJF). Precipitation and temperature data are available at monthly resolution since 1921 for nine weather stations in Trentino (Fig. 1). Instrumental data series were obtained from Meteotrentino (Provincia Autonoma di Trento) weather stations and the agro-meteorological network of the Istituto Agrario San Michele all'Adige (http: //hydstraweb.provincia.tn.it/web.htm). The NAO index data were provided by the Climate Analysis Section, NCAR, Boulder, USA (Hurrell, 1995).

Sub-samples for U-series age determination were taken along the growth axis of stalagmite ER 76 and analysed using a Finnigan MAT 262 RPQ thermal ionisation mass spectrometer (TIMS) with a double filament technique at the Heidelberg Academy of Sciences. Chemical preparation of the samples was similar as described by Scholz et al. (2004). The calibration of the $U$ and Th spikes used in the Heidelberg laboratory is described in Hoffmann et al. (2007). All ages were calculated using the half-lives reported by Cheng et al. (2000). By default, all ages were corrected for detrital contamination assuming a ${ }^{232} \mathrm{Th} /{ }^{238} \mathrm{U}$ mass ratio of 3.8 and $\left({ }^{230} \mathrm{Th}\right),\left({ }^{234} \mathrm{U}\right)$ and $\left({ }^{238} \mathrm{U}\right)$ in secular equilibrium. Except for one sample (ER 76-20.5), the correction is within the dating uncertainties.

Samples for stable oxygen and carbon isotope analysis were micromilled at $100 \mu \mathrm{m}$ intervals between 0 and $8 \mathrm{~mm}$ distance from top (dft) and at $\sim 250 \mu \mathrm{m}$ intervals for the remainder of stalagmite ER 76. For ER 77, stable isotope samples were micromilled on the upper $20 \mathrm{~mm}$ dft at $100 \mu \mathrm{m}$ increments (for methodological details, see Spötl and Mattey, 2006). All measurements were performed using an online, automated carbonate preparation system linked to a triple collector gas source isotope ratio mass spectrometer at Innsbruck University. All values are reported relative to the VPDB standard. Long-term precision of the $\delta^{13} \mathrm{C}$ and $\delta^{18} \mathrm{O}$ values, estimated as the $1 \sigma$-standard deviation of replicate analyses, is 0.06 and $0.08 \%$, respectively (Spötl and Vennemann, 2003). Drip water from the drip sites feeding stalagmites ER 76 and ER 77 was collected monthly and analysed for its stable carbon and oxygen isotope composition (for analytical details, see Spötl, 2005).

For spectral analysis of the stable isotope signals of ER 76, we used the software REDFIT 3.8 (Schulz and Mudelsee, 2002) with the following parameter settings: oversampling factor, $\mathrm{OFAC}=20.0$; highest frequency factor, $\mathrm{HIFAC}=1.0$; number of overlapping (50\%) segments, $n_{50}=2$; Welch taper function; detrending method: segment-wise linear; biascorrection using 10000 Monte Carlo simulations; AR(1) upper levels from chi-squared distribution.

The ${ }^{14} \mathrm{C}$ analyses were carried out on $\sim 10 \mathrm{mg}$ of calcite sampled using a dentist drill with a diameter of $1.3 \mathrm{~mm}$. One sample encompasses a time span ranging from 16 (ER 76J) to 52 a (ER 76M) depending on the growth rate of the respective part of the stalagmite. All samples were taken near the vertical growth axis of the stalagmite. Drilling was performed in a glove box in a $\mathrm{CO}_{2}$-free atmosphere. The calcite powder was then acidified in vacuo using $\mathrm{HCl}$, and $\mathrm{CO}_{2}$ was combusted in the Heidelberg radiocarbon laboratory. The resultant carbon-iron-mixture was analysed by accelerator mass spectrometry at the radiocarbon laboratory of the University of Lund, Sweden. The analytical uncertainty is smaller than $0.4 \mathrm{pmC}$ (percent modern carbon) for all samples. 
Table 2. Results of ${ }^{14} \mathrm{C}$ dating.

\begin{tabular}{|c|c|c|c|c|c|c|c|c|}
\hline Sample & $\begin{array}{l}\text { Heidelberg } \\
\text { analysis } \\
\text { number }\end{array}$ & $\begin{array}{l}\text { Lund lab } \\
\text { number }\end{array}$ & $\begin{array}{l}\text { Distance from } \\
\text { top [mm] }\end{array}$ & $\begin{array}{l}\text { Sample } \\
\text { age [a] }\end{array}$ & $\begin{array}{r}1 \sigma \text {-error } \\
{[\mathrm{a}]}\end{array}$ & $\begin{array}{r}{ }^{14} \mathrm{C} \text { activity } \\
{[\mathrm{pmC}]}\end{array}$ & $\begin{array}{l}\text { Error } \\
{[\mathrm{pmC}]}\end{array}$ & $\begin{array}{r}\delta^{13} \mathrm{C} \\
{[\% o]}\end{array}$ \\
\hline ER-76 L & 25236 & 50079 & 10.5 & 176 & 10 & 83.18 & 0.34 & -0.2 \\
\hline ER-76 M & 25237 & 50080 & 18.8 & 396 & 10 & 71.49 & 0.31 & -4.6 \\
\hline ER-76 A & 25022 & 50001 & 22.3 & unknown & & 73.18 & 0.28 & -3.6 \\
\hline ER-76 B & 25023 & 50002 & 24.9 & unknown & & 69.75 & 0.37 & -17.8 \\
\hline ER-76 N & 25238 & 50081 & 33.6 & unknown & & 66.99 & 0.28 & -9.3 \\
\hline ER-76 C & 25024 & 50003 & 39.4 & unknown & & 64.45 & 0.30 & -5.9 \\
\hline ER-76 D & 25025 & 50004 & 44.3 & 2613 & 135 & 65.17 & 0.32 & -13.9 \\
\hline ER-76 E & 25026 & 50005 & 60.7 & 3302 & 103 & 62.69 & 0.28 & -15.5 \\
\hline ER-76 F & 25027 & 50006 & 87.7 & 3773 & 154 & 59.42 & 0.27 & -12.3 \\
\hline ER-76 G & 25028 & 50007 & 107.75 & 4102 & 135 & 58.09 & 0.27 & -7.0 \\
\hline ER-76 H & 25029 & 50008 & 130.9 & 4583 & 155 & 56.11 & 0.27 & -7.9 \\
\hline ER-76 I & 25030 & 50009 & 145.4 & 4865 & 168 & 55.35 & 0.27 & -12.4 \\
\hline ER-76 J & 25031 & 50010 & 167.8 & 5162 & 153 & 53.89 & 0.26 & -7.6 \\
\hline
\end{tabular}

${ }^{14} \mathrm{C}$ activity of the thirteen samples of stalagmite ER 76. The sample ages and the corresponding errors are based on the lamina counting age model (see text for details). For the two samples at the top (i.e., $\mathrm{L}$ and $\mathrm{M}$ ) a maximum error of $10 \mathrm{a}$ was assumed. The four samples labelled by $\mathrm{A}, \mathrm{B}, \mathrm{C}$ and $\mathrm{N}$ are from the section between 42 and $19 \mathrm{~mm}$ dft, where the age model is uncertain (Fig. 2). ${ }^{13} \mathrm{C}$ values were measured by Accelerator Mass Spectrometry and might be affected by fractionation effects. Thus, these values may differ from the $\delta^{13} \mathrm{C}$ values determined with the triple collector gas source isotope ratio mass spectrometer (Figs. 3 and 9).

The def was calculated as follows (Genty et al., 1999):

$\mathrm{dcf}=1-\frac{a^{14} \mathrm{C}_{\mathrm{stal}}}{a^{14} \mathrm{C}_{\mathrm{atm}}} \times 100 \%$,

where $a^{14} \mathrm{C}_{\text {stal }}$ is the ${ }^{14} \mathrm{C}$ activity of stalagmite calcite and $a^{14} \mathrm{C}_{\mathrm{atm}}$ is the atmospheric ${ }^{14} \mathrm{C}$ activity at the time of deposition. $a^{14} \mathrm{C}_{\mathrm{atm}}$ was calculated with a Matlab routine, which utilises the IntCal04 calibration curve (Reimer et al., 2004), the sample age and the corresponding $1 \sigma$-error of the age model. 10000 iterations were performed in order to create a probability distribution with the sample age as the mean value and the $1 \sigma$-error as the standard deviation. To calculate $a^{14} \mathrm{C}_{\mathrm{atm}}$ and the corresponding uncertainty, the ${ }^{14} \mathrm{C}$ activities of these 10000 ages were averaged, and the $1 \sigma$-error was calculated. The dcf was calculated using Eq. (1), and the error was calculated by error propagation.

Lamina counting for ER 76 was performed on a different slab of the stalagmite than U-series dating and the other proxy analyses. Lamina thickness was calculated as the mean of the thickness measured along three parallel traverses near the vertical growth axis to average over lateral variations due to the irregular surface of successive growth layers. Details of the methodology are provided by Frisia et al. (2003).

\section{Results}

\subsection{Modern relationship between the NAO and winter climate}

The correlation coefficients between the amount of winter precipitation (DJF) at the nine investigated stations in
Trentino (Fig. 1) and the winter NAO index (DJF) are all negative and range from -0.40 to -0.20 . For stations Passo Rolle and Tione (Fig. 1), the correlation is not significant at the $95 \%$-confidence level. The correlation coefficients between winter temperature and the winter NAO index are all positive and range from 0.30 to 0.56 . For station Pinzolo (Fig. 1), the correlation is not significant at the $95 \%$ confidence level.

These results suggest an influence of the NAO on winter climate at the cave site and confirm the results of Efthymiadis et al. (2007), i.e., $\mathrm{NAO}^{+}$phases are associated with drier and warmer winter conditions, whereas $\mathrm{NAO}^{-}$phases correspond to wetter and colder winters.

\subsection{Chronology}

The results of U-series dating are shown in Table 1. Figure 2 a shows the new U-series chronology for ER 76. Two of the previously published ages were discarded (ER 76-8a and ER 76B, McDermott et al., 1999, not shown in Fig. 2) because they disagree with the U-series ages determined in this study. This confirms the results of Frisia et al. (2006), who suspected that these ages are not accurate on the basis of lamina counting. Apart from these two ages, the new Useries ages confirm the previous data. There is a minor age inversion between 150 and $160 \mathrm{~mm} \mathrm{dft}$, where the previously published age (McDermott et al., 1999) is slightly older than the new value (Fig. 2a). Based on the U-series ages, the stalagmite exhibits a rather constant growth rate of $\sim 60 \mu \mathrm{m} \mathrm{a}^{-1}$ in the interval between approximately 8 and $2 \mathrm{ka}$. 
In order to establish an age model on the basis of the determined ages, the mixed-effect regression model of Heegaard et al. (2005) was applied. The calculated age model is shown as a dashed line in Fig. $2 \mathrm{~b}$ with its corresponding $95 \%$-confidence limits. The maximum $2 \sigma$-age uncertainty is $800 \mathrm{a}$ at the bottom and $300-400 \mathrm{a}$ for the rest of the stalagmite. Annual lamina counting revealed a major hiatus at $42 \mathrm{~mm}$ dft and several minor hiatuses between 42 and $19.8 \mathrm{~mm}$ dft, which must be accounted for in the age model.

The stalagmite was actively growing at the time of collection (1993 AD, McDermott et al., 1999). Consequently, the annual layers can be counted from the top down as far as the first hiatus providing an age for the upper $19.8 \mathrm{~mm} \mathrm{dft}$. This section encompasses the last 420 a (Fig. 2b, see Frisia et al., 2003, for details). Between $42 \mathrm{~mm} \mathrm{dft}$ and the base of the speleothem, no hiatuses were detected providing a floating, annually resolved chronology. The floating chronology was adjusted to the U-series age model by determining the age for the base of the stalagmite minimising the average age difference between both age models. The best agreement is obtained for a basal age of $8.038 \mathrm{ka}$, which is in good agreement with the U-series age model (i.e., $8.2 \pm 0.8 \mathrm{ka}$ ). Both age models generally show a good agreement, and the lamina counting age model is always within the $95 \%$-confidence limits of the U-series age model (Fig. 2b). This confirms the annual origin of the lamination and that U-series dating of ER 76 provides reliable ages despite the low $U$ content. In the following, all data are presented and discussed on the basis of the lamina counting age model (Fig. 2b).

\subsection{Stable isotopes, lamina thickness, calcite texture and ${ }^{14} \mathrm{C}$}

Figure 3 shows a compilation of the different proxies measured on stalagmite ER 76. The high resolution $\delta^{13} \mathrm{C}$ profile generally agrees with the lower resolution data obtained previously (McDermott et al., 1999). Trends in $\delta^{18} \mathrm{O}$ are also consistent, although we note an offset of $\sim 0.5 \%$ o between the low and the high-resolution profiles. Inter-laboratory comparison showed that this is not a calibration issue, but seems to be related to the fact that the two data series were not obtained on exactly the same longitudinal section of the stalagmite. Also shown in Fig. 3 are the lamina thickness data and variations in calcite texture (from McDermott et al., 1999, adjusted to the new time scale). Textures coded 3 or higher are indicative of changes in the stacking of crystallites related to changes in environmental parameters, most notably drip water supersaturation and the effect of impurities (Frisia and Borsato, 2010). Further details and exemplary figures are given in McDermott et al. (1999), Frisia et al. (2000), Frisia and Borsato (2010) as well as in Sect. 4.1.1.

The $\delta^{18} \mathrm{O}$ signal shows high variability throughout the record. The highest average values are observed at the beginning of the record, between 8.0 and $7.4 \mathrm{ka}$. The lowest average values are recorded after the hiatus in the youngest
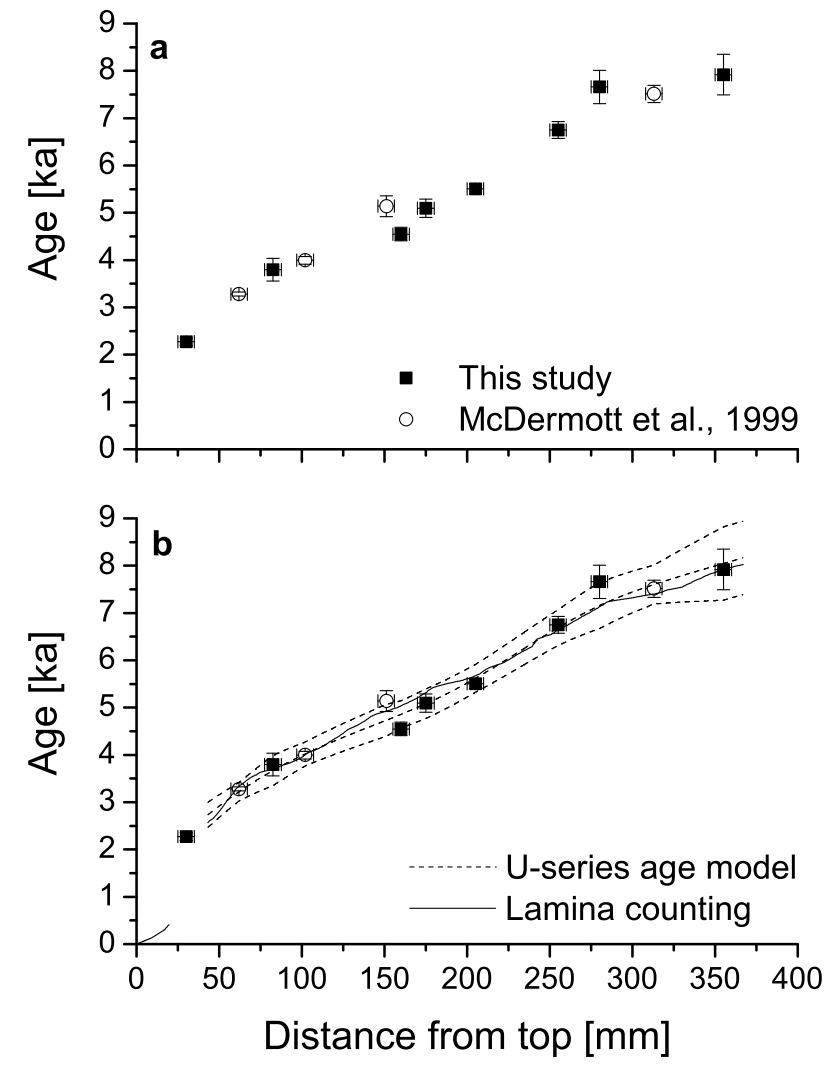

Fig. 2. (a) U-series ages determined for ER 76 in this (filled squares) and a previous study (open circles, McDermott et al., 1999) plotted against the distance from top of the stalagmite. The McDermott et al. (1999) ages were recalculated using the most recent half-lives (Cheng et al., 2000) and corrected for detrital contamination as described in the text. Error bars include $2 \sigma$-age uncertainties and thickness of the individual samples. (b) Age models for stalagmite ER 76. The age model based on the U-series ages was calculated using the algorithm of Heegaard et al. (2005, dashed line). The enveloping lines represent the corresponding $95 \%$-confidence limits. The bold, solid line shows the age model based on counting of annual lamina from the bottom of the stalagmite. Further details are given in the text.

part of the stalagmite. The $\delta^{13} \mathrm{C}$ signal shows high values at the beginning of the record (i.e., between 8.0 and $7.4 \mathrm{ka}$ ), and steadily decreasing values afterwards. After the hiatus, approximately $200 \mathrm{a}$ ago, $\delta^{13} \mathrm{C}$ values show a rapid shift to more positive values. The lamina thickness profile also shows high variability throughout the Holocene. Laminae thicker than $100 \mu \mathrm{m}$ are detected at 7.9, 7.4, 6.5, 5.5, 4.9 and $3.7 \mathrm{ka}$ as well as in the most recent part of the stalagmite (Frisia et al., 2003). The dcf (Table 2) shows an increasing trend from $\sim 6$ to $\sim 15 \%$ within the last $5 \mathrm{ka}$. Calcite texture codes show high variability, but, in general, decreasing values reflecting a trend from dendritic textures at the bottom of the stalagmite to short columnar textures at the top. 


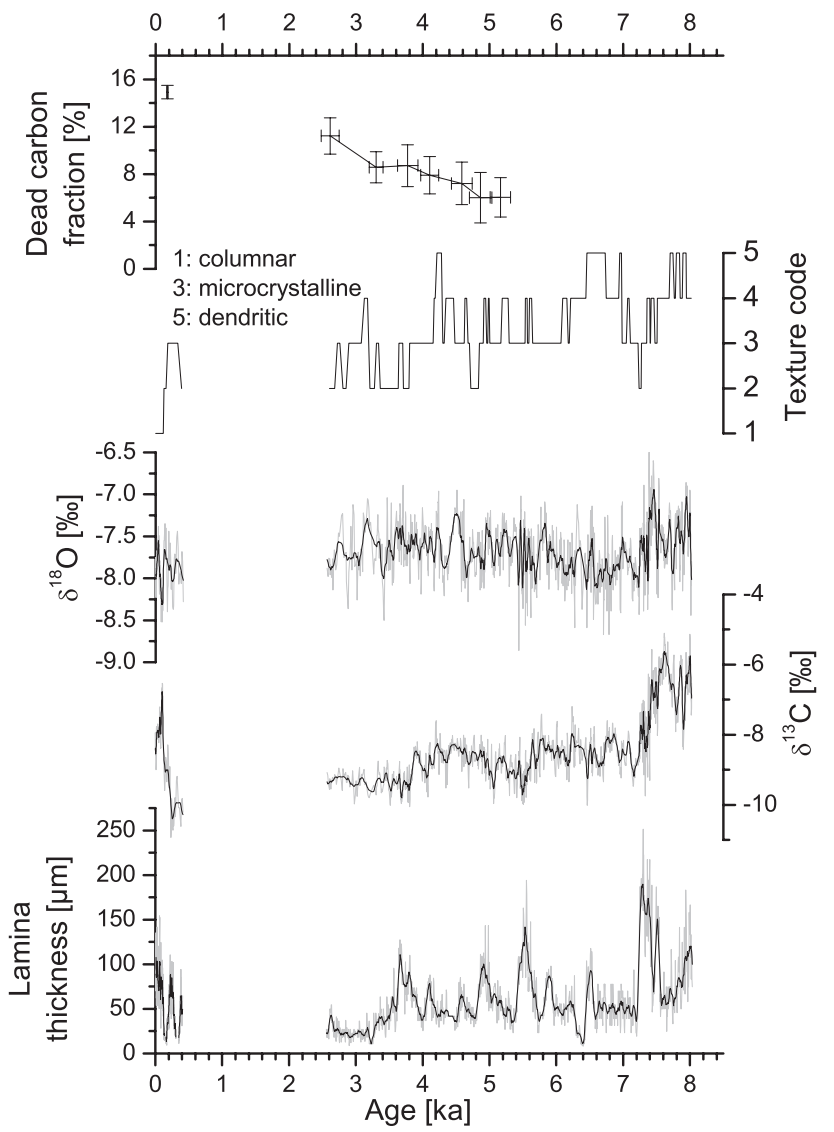

Fig. 3. Comparison of the different proxies measured on stalagmite ER 76. All data are shown on the lamina-counting age model. Values of dead carbon fraction are shown with $1 \sigma$-error bars. The texture code has been taken from McDermott et al. (1999) and adjusted to the new age scale. Stable isotope and lamina thickness data are shown in light grey, and the solid lines are the corresponding 10point running means.

\subsection{Spectral analysis}

Figure 4 shows the results of spectral analysis of the stable isotope signals. Both the $\delta^{18} \mathrm{O}$ and $\delta^{13} \mathrm{C}$ data show significant peaks at periods of $60-70$, around 40 and around 25 a. $\delta^{18} \mathrm{O}$ also shows significant peaks between 45 and 50 as well as at 32-37 a. In addition, there is a peak around $110 \mathrm{a}$ in the $\delta^{13} \mathrm{C}$ data, which is only slightly below the $90 \%$-false alarm level. Except for the cycle between 32 and 37 a in $\delta^{18} \mathrm{O}$, all observed periodicities can be assigned within the bandwidth to solar variability, which shows significant cycles at 104, 60, 45, 42 and 27 a (Ogurtsov et al., 2002; Peristykh and Damon, 2003). The observed 25 -a periodicity may also correspond to NAO variability, which shows a significant cycle of 25 a (Cook et al., 1998).
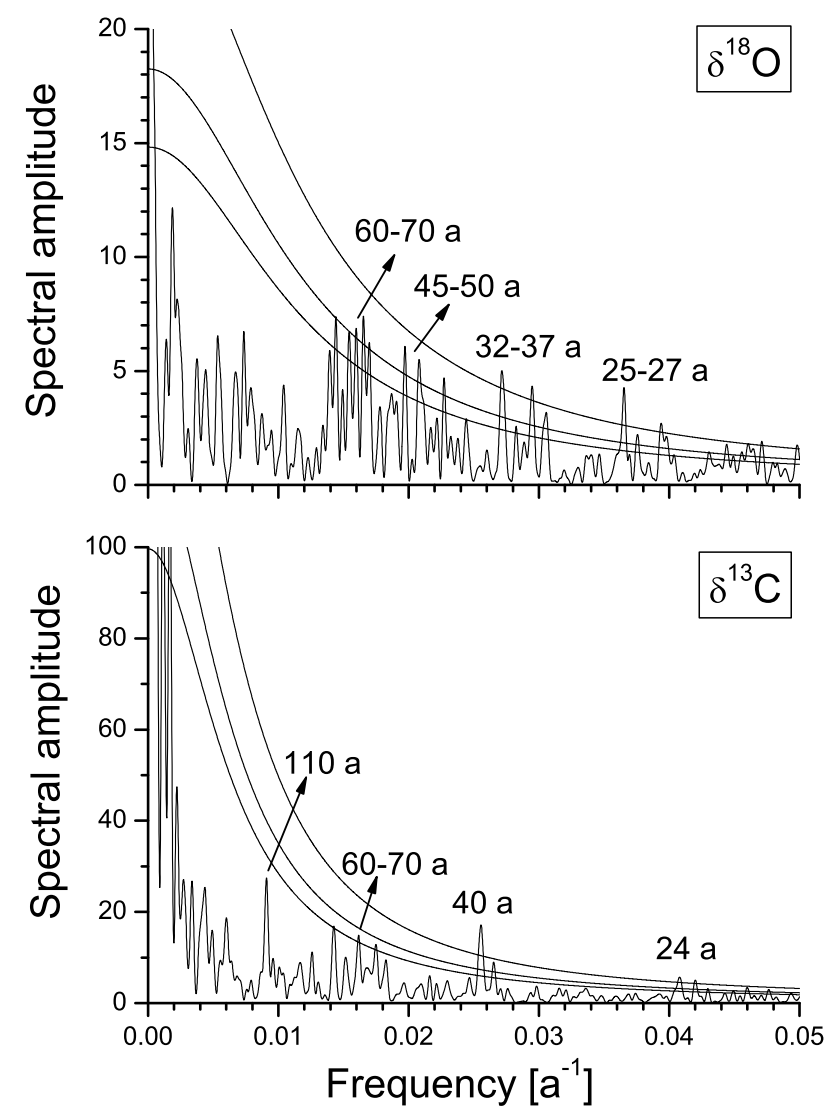

Fig. 4. Lomb-Scargle spectra of the $\delta^{18} \mathrm{O}$ (upper panel) and $\delta^{13} \mathrm{C}$ (lower panel) records of ER 76. The straight curves are the corresponding $90 \%, 95 \%$ and $99 \%$-false-alarm levels indicating the statistical significance of the individual peaks. The 6-dB bandwidth, determining the frequency resolution, is $0.00044 \mathrm{a}^{-1}$.

\section{Discussion}

\subsection{Climatic interpretation of the proxies}

\subsubsection{Textural variation and lamina thickness}

The significance of the different textures observed in ER 76 was extensively described and illustrated in McDermott et al. (1999) and Frisia et al. (2000). The short columnar texture (texture code 1) reflects deposition at relatively constant drip rate, constant and low supersaturation with respect to calcite and low abundance of impurities. At Grotta di Ernesto, supersaturation with respect to calcite is directly related to degassing of $\mathrm{CO}_{2}$ (Frisia et al., 2011). Microcrystalline (code 3) and dendritic textures (code 5) can be interpreted as a progressive distortion of the proper columnar fabric. The trend from dendritic (code 5) to microcrystalline (code 3) and columnar textures in ER 76 during the Holocene (Fig. 3) can be interpreted as a progressive trend towards relatively low supersaturation, less impurities and a change from 
variable to relatively constant drip rate (Frisia and Borsato, 2010).

The early growth phase of ER 76 (between 8.0 and $7.3 \mathrm{ka}$ ), which is characterised by predominant dendritic textures (Fig. 3), thus, suggests large changes in supersaturation and variable drip rate. This may indicate stronger seasonality than today with respect to both rainfall and temperature since the latter modulates $\mathrm{CO}_{2}$ degassing. In contrast, the youngest growth phase suggests less variable drip rates and a weaker seasonal contrast (Fig. 3). Phases of highly variable conditions also occurred around 6.6 and $4.2 \mathrm{ka}$ (Fig. 3).

Lamina thickness and its dependence on temperature in Grotta di Ernesto stalagmites was discussed extensively in Frisia et al. (2003). Stalagmite growth rates depend on winter temperature via surface processes, such as enhanced soil $\mathrm{CO}_{2}$ production, and cave processes, such as rapid degassing of $\mathrm{CO}_{2}$ (Fairchild et al., 2007; Frisia et al., 2011). The positive correlation between winter temperature and the winter NAO index observed for eight out of nine weather stations from the area (Sect. 3.1), thus, suggests that periods of high lamina thickness correspond to $\mathrm{NAO}^{+}$-phases.

\subsubsection{Reproducibility of stable isotope signals and tests for isotopic equilibrium}

The assumption that stable isotope signals recorded by ER 76 reflect past climate variability rather than drip-site specific processes was tested by analysing the top section of ER 77 . The U content of ER 77 is even lower than that of ER 76, and its structure in the older part is rather porous, which may have led to post-depositional open-system modification of the U-series system. Thus, it was not possible to establish a U-series chronology and the comparison was only carried out for the last 300 a where a robust lamina-counting chronology is available for both stalagmites (Frisia et al., 2003). It is evident from Fig. 5 that the $\delta^{13} \mathrm{C}$ and $\delta^{18} \mathrm{O}$ values of both stalagmites are within the same range and show very similar trends, which is confirmed by the rather high correlation coefficients of $R=0.82$ [0.73; 0.87] for $\delta^{13} \mathrm{C}$ and $R=0.46$ [0.29; 0.60] for $\delta^{18} \mathrm{O}$ (numbers in brackets denote $95 \%$-confidence intervals for the correlation obtained from block bootstrap resampling, Mudelsee, 2003, which takes into account serial dependence). Consequently, we interpret the stable isotope signals recorded by ER 76 in terms of past climate variability (Dorale and Liu, 2009).

We used several approaches to test whether calcite precipitation occurred under isotopic equilibrium. Firstly, the $\delta^{18} \mathrm{O}$ and $\delta^{13} \mathrm{C}$ values of speleothem calcite were compared with those expected from the isotopic composition of recent drip water. The average $\delta^{13} \mathrm{C}$ value measured on the dissolved inorganic carbon (DIC) of the drip water collected between June 2002 and June 2007 at the ER 76 drip site is $-11.3 \pm 0.6 \%$. For the present-day cave temperature of $6.7^{\circ} \mathrm{C}$, a $\delta^{13} \mathrm{C}$ value of $-10.3 \pm 0.6 \%$ o would be expected for speleothem calcite precipitated in isotopic equilibrium with the bicarbonate in the drip water (Romanek et al., 1992). The $\delta^{13} \mathrm{C}$ values measured on ER 76 are significantly higher than this in most parts of the record. $\delta^{13} \mathrm{C}$ values lower than $-9.5 \%$ only occur around 5.5, 5.0 and $3.7 \mathrm{ka}$ as well as between 400 and $200 \mathrm{a}$ (Fig. 3). The $\delta^{13} \mathrm{C}$ values of the last $100 \mathrm{a}$ are between -8.4 and $-6.7 \%$ (Fig. 5). This indicates that carbon isotope fractionation between the bicarbonate in the drip water and speleothem calcite in ER 76 did not occur under conditions of isotopic equilibrium and confirms the results of carbon mass-balance modelling, which suggests that $\delta^{13} \mathrm{C}$ values of both DIC in cave drip water and speleothem calcite at Grotta di Ernesto are affected by rapid kinetic degassing of $\mathrm{CO}_{2}$. For drip water with a $\delta^{18} \mathrm{O}$ value of $-9.2 \pm 0.4 \%$, the expected $\delta^{18} \mathrm{O}$ value of speleothem calcite precipitated in isotopic equilibrium is $-7.6 \pm 0.4 \%$ ( Kim and O'Neil, 1997), which is within the range of the values measured in ER 76 (Figs. 3 and 5, the mean $\delta^{18} \mathrm{O}$ value is $-7.69 \%$ ). This suggests that oxygen isotope fractionation occurred close to isotopic equilibrium, whereas carbon isotopes were influenced by rapid degassing. This is in agreement with modelling studies showing that rapid degassing of $\mathrm{CO}_{2}$ should have a lower effect on speleothem $\delta^{18} \mathrm{O}$ values due to oxygen isotope exchange between dissolved bicarbonate and drip water (Scholz et al., 2009; Mühlinghaus et al., 2009; Dreybrodt and Scholz, 2011).

We also performed the classic "Hendy test" (Hendy, 1971 ), which requires that the $\delta^{18} \mathrm{O}$ and $\delta^{13} \mathrm{C}$ values measured along single growth layers neither show a progressive increase away from the growth axis nor are positively correlated. However, modelling has shown that speleothem stable isotope values may have been influenced by stable isotope fractionation under disequilibrium conditions even if the Hendy test is negative (Mühlinghaus et al., 2009). Four "Hendy tests" were performed on ER 76 (Fig. 6). While $\delta^{13} \mathrm{C}$ shows increasing values away from the growth axis at all depths, the $\delta^{18} \mathrm{O}$ data vary around a constant value. An exception is the Hendy test at $50 \mathrm{~mm}$ dft (panel b), which shows a rise in $\delta^{18} \mathrm{O}$ and also a significant positive correlation between $\delta^{18} \mathrm{O}$ and $\delta^{13} \mathrm{C}$. The test at $106 \mathrm{~mm}$ dft (panel c) also exhibits a significant positive correlation.

In addition, the correlation coefficients between $\delta^{13} \mathrm{C}$ and $\delta^{18} \mathrm{O}$ values as well as between stable isotopes and lamina thickness along the growth axis of the stalagmite were calculated. We note that correlations between stable isotope values along the growth axis may also be related to climate variability and are, thus, a less strict criterion to test for kinetic isotope fractionation (Mickler et al., 2006). The $\delta^{13} \mathrm{C}$ and $\delta^{18} \mathrm{O}$ values show a significant correlation of 0.29 [0.23; 0.34] indicating a potential influence of fractionation under disequilibrium conditions probably modulated by rapid degassing of $\mathrm{CO}_{2}$ (Frisia et al., 2011). $\delta^{13} \mathrm{C}$ values are also significantly correlated with lamina thickness, and the correlation coefficient is 0.30 [0.25; 0.35]. Numbers in brackets denote $95 \%$-confidence intervals for the correlation obtained from block bootstrap resampling, which takes into account serial 

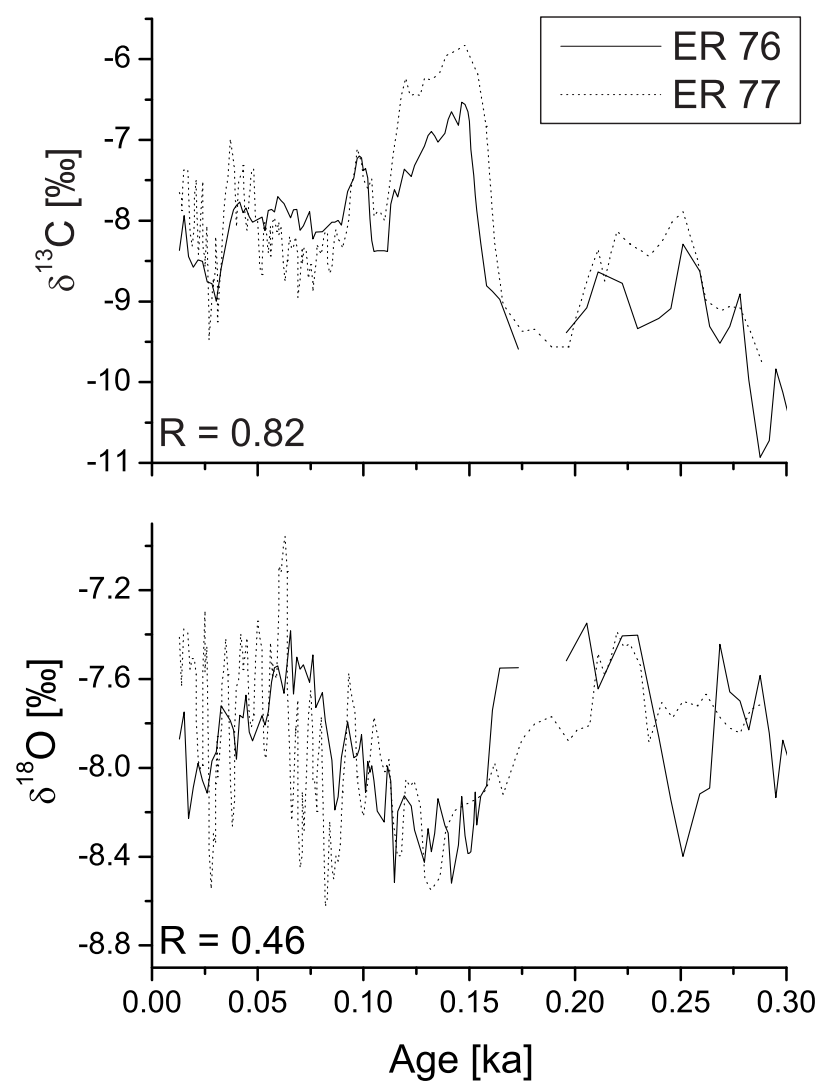

Fig. 5. Comparison of the $\delta^{13} \mathrm{C}$ and $\delta^{18} \mathrm{O}$ profiles of ER 76 (solid line) and ER 77 (dotted line) for the last $300 \mathrm{a}$. The age models of both stalagmites are based on lamina counting (Frisia et al., 2003). Around $1700 \mathrm{AD}$ both stalagmites show a hiatus (ER 76: $\sim 50 \mathrm{a}$, ER77: 100 a, Frisia et al., 2003), and the subsequent laminae are very thin (i.e., between 10 and $30 \mu \mathrm{m}$ ). This precludes a direct comparison of the older parts of the records.

dependence (Mudelsee, 2003). This is not surprising since both calcite precipitation and enrichment in $\delta^{13} \mathrm{C}$ at Grotta di Ernesto are driven by degassing and, as a consequence, supersaturation with respect to calcite. Thus, in case of isotope fractionation under disequilibrium conditions, both $\delta^{13} \mathrm{C}$ and lamina thickness should increase with increasing calcite precipitation rate. The effect on $\delta^{18} \mathrm{O}$, in contrast, should be much lower due to oxygen isotope exchange between drip water and dissolved bicarbonate (Scholz et al., 2009). $\delta^{18} \mathrm{O}$ indeed only shows a weak correlation with lamina thickness $(R=0.09[0.03 ; 0.15])$.

In summary, all approaches suggest an influence of stable isotope fractionation under conditions of disequilibrium, which is particularly pronounced for carbon isotope fractionation.

\subsection{3 $\delta^{13} \mathrm{C}$ variability}

The $\delta^{13} \mathrm{C}$ signal recorded in speleothems depends on several environmental and isotope fractionation processes, which occur at the surface, in the soil, the epikarst, the cave and on the stalagmite surface (Dreybrodt and Scholz, 2011). These processes are directly or indirectly related to climate, and their interactions render the interpretation of speleothem $\delta^{13} \mathrm{C}$ data a non-trivial task.

For Grotta di Ernesto, the processes influencing the $\delta^{13} \mathrm{C}$ values of soil air, soil water, drip water and speleothem calcite are extraordinarily well understood due to the extensive cave monitoring programme and quantitative carbon massbalance modelling (Frisia et al., 2011). Soil monitoring data clearly show that soil $p \mathrm{CO}_{2}$, soil gas $\delta^{13} \mathrm{C}$ and soil water $\delta^{13} \mathrm{C}$ values at Grotta di Ernesto reflect surface temperature changes (Frisia et al., 2011). More negative soil water $\delta^{13} \mathrm{C}$ values correspond to warmer surface temperatures due to the temperature sensitivity of root respiration and bacterial decomposition of soil organic matter, which was probably derived from $\mathrm{C}_{3}$ plants for the entire period of stalagmite growth. The $\delta^{13} \mathrm{C}$ values of cave drip water, however, do not reflect the $\delta^{13} \mathrm{C}$ values of soil water, but are substantially altered by dissolution of host rock and rapid degassing of $\mathrm{CO}_{2}$ both inside the cave and on the surface of the stalagmite. In total, these processes result in speleothem $\delta^{13} \mathrm{C}$ values higher by $\sim 5 \%$ o than the initial values in the epikarst, and the largest proportion of the enrichment is due to rapid degassing of $\mathrm{CO}_{2}$ (Frisia et al., 2011). Speleothem $\delta^{13} \mathrm{C}$ values at Grotta di Ernesto, thus, predominantly reflect changes in degassing of $\mathrm{CO}_{2}$ in response to cave ventilation rather than processes occurring in the soil zone.

About $80 \%$ of the annual calcite precipitation at Grotta di Ernesto occurs during winter months when surface temperature is lower than the cave temperature and cave air $p \mathrm{CO}_{2}$ is lower than during summer (Miorandi et al., 2010). During long and severe winters, the effect of rapid degassing on speleothem $\delta^{13} \mathrm{C}$ values should, thus, be particularly pronounced, whereas it should be attenuated during milder winters. On the seasonal to annual time scale, we, thus, interpret more positive $\delta^{13} \mathrm{C}$ values as being indicative of cold and long winters and more negative $\delta^{13} \mathrm{C}$ values as reflecting relatively mild and short winters. This interpretation agrees with our interpretation of the lamina thickness record and its dependence on temperature via soil $\mathrm{CO}_{2}$ production and rapid degassing of $\mathrm{CO}_{2}$ (Frisia et al., 2003, 2011).

The observed long-term decrease in $\delta^{13} \mathrm{C}$ between 8.0 and $2.5 \mathrm{ka}$ (Fig. 3), however, is unlikely to be related to changes in cave ventilation and degassing as this would require a progressive reduction in ventilation. A more likely explanation for the millennial-scale decrease of the $\delta^{13} \mathrm{C}$ values is a progressive change in soil thickness and composition above the cave during the Holocene. A mature soil containing more soil organic matter is characterised by higher soil $p \mathrm{CO}_{2}$ values and, as a consequence, lower soil $\delta^{13} \mathrm{C}$ values (Cerling, 1984). This scenario is also supported by the increase in dcf, which coincides with a trend towards more negative $\delta^{13} \mathrm{C}$ values (Fig. 3). An alternative explanation would be a change in the type of vegetation above the cave. Pollen 

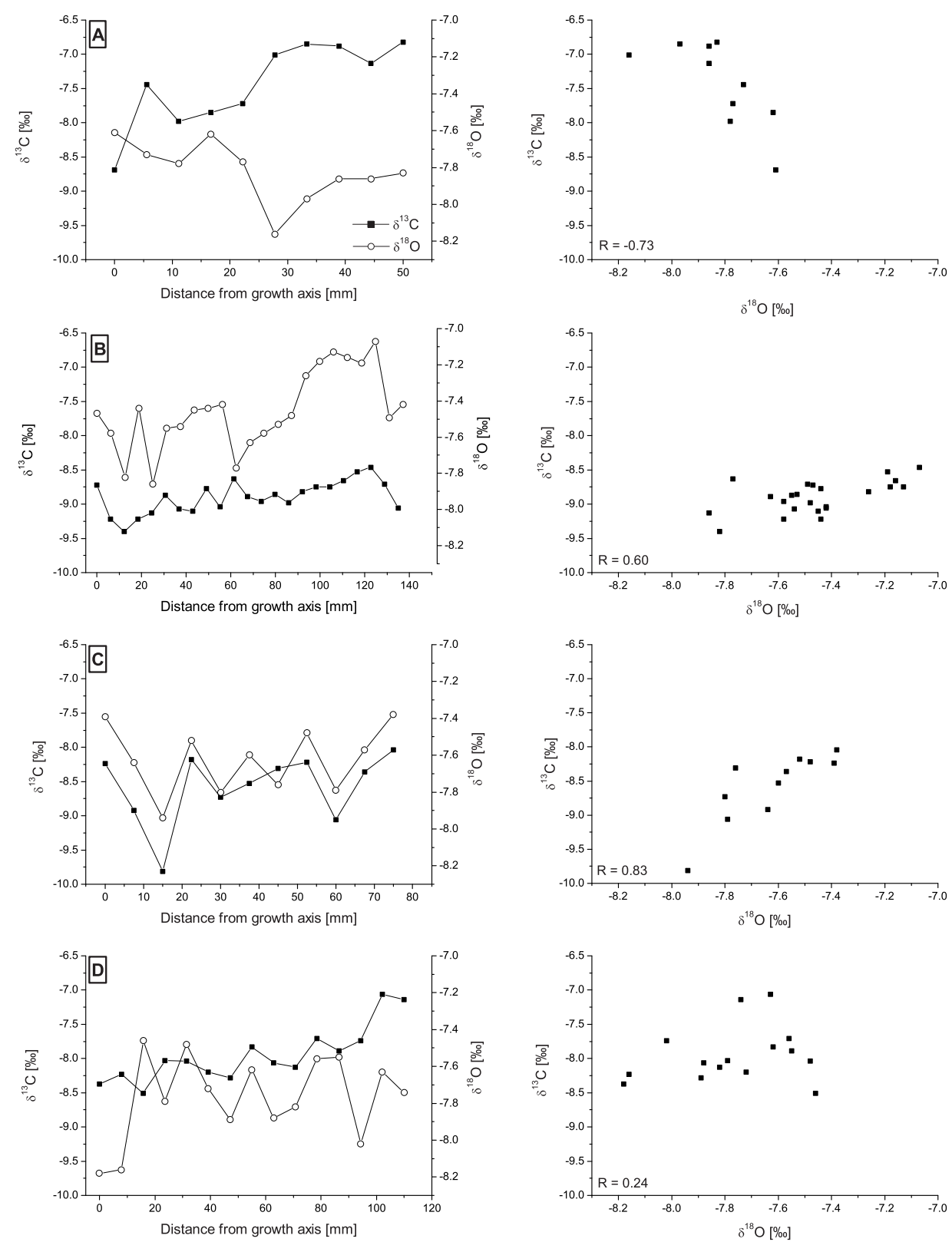

Fig. 6. Four "Hendy tests" for ER 76 conducted at 10, 50, 106 and $250 \mathrm{~mm}$ dft (A-D). The left side shows $\delta^{18} \mathrm{O}$ and $\delta^{13} \mathrm{C}$ values measured on a single growth layer plotted against the distance from the growth axis. Increasing values away from the axis are indicative of isotope fractionation under disequilibrium conditions. The right side shows the corresponding $\delta^{13} \mathrm{C}$ vs. $\delta^{18} \mathrm{O}$ plots. Kinetic isotope fraction is indicated by a positive correlation.

data from Lago di Lavarone (Fig. 1) show that the vegetation association consisted of broadleaf (Fagus), Abies and Picea between ca. 8 and ca. $2 \mathrm{ka}$ and was, thus, similar to that observed today (Filippi et al., 2007). It is, thus, unlikely that the long-term decrease in $\delta^{13} \mathrm{C}$ between 8.0 and $2.5 \mathrm{ka}$ (Fig. 3) is related to changes in vegetation association. Prior to $8 \mathrm{ka}$, the vegetation mostly consisted of xerophytes and conifers. It is interesting that ER 76 started to grow when broadleaves appeared in the biome, which suggests a relationship between deciduous trees and the supersaturation of karst waters in the region as suggested by Frisia and Borsato (2010).

In summary, there are several climate-related effects, which may have influenced the $\delta^{13} \mathrm{C}$ signal of ER 76. The most important process on the millennial time-scale is the development of the soil profile. On shorter time scales, the $\delta^{13} \mathrm{C}$ variability is modulated by isotope fractionation under 
conditions of disequilibrium controlled by inter-annual differences in degassing of $\mathrm{CO}_{2}$.

\subsection{4 $\delta^{18} \mathrm{O}$ variability}

The $\delta^{18} \mathrm{O}$ signal in Grotta di Ernesto speleothem calcite is also influenced by several, partly competing factors. As for $\delta^{13} \mathrm{C}$, processes above (i.e., processes affecting the $\delta^{18} \mathrm{O}$ of precipitation and in the soil zone) and inside the cave (i.e., isotope fractionation processes) must be considered (Lachniet, 2009).

The $\delta^{18} \mathrm{O}$ value of the precipitation falling at the cave site seems to be mainly related to temperature as indicated by the high correlation coefficient $(R=0.78[0.56 ; 0.89]$, number of observations, $N=31$ ) between the monthly means of temperature and rainfall $\delta^{18} \mathrm{O}$ at the meteorological station at Lavarone (Fig. 1). The correlation between precipitation amount and rainfall $\delta^{18} \mathrm{O}$, in contrast, is not significant $(R=0.22[-0.02 ; 0.42], N=43)$. This does not confirm the previous interpretation of McDermott et al. (1999), who related the $\delta^{18} \mathrm{O}$ signal of ER 76 to changes in rainfall amount.

In principle, the $\delta^{18} \mathrm{O}$ value of cave drip water should record the weighted mean $\delta^{18} \mathrm{O}$ value of the water infiltrating the karst aquifer (i.e., rainfall minus potential evapotranspiration, Wackerbarth et al., 2010). This assumption was tested for Grotta di Ernesto using precipitation data from Lavarone and drip water data from the ER 76 drip site. Potential evapo-transpiration was calculated using the equation of Thornthwaite (1948). The calculated weighted annual mean of the $\delta^{18} \mathrm{O}$ values of the water infiltrating between 2004 and 2007 ranges from -12.3 to $-9.8 \%$. The mean annual $\delta^{18} \mathrm{O}$ values of the drip water at the ER 76 drip site in the same period are between -9.7 and $-8.8 \%$. The $\delta^{18} \mathrm{O}$ values of the drip water, thus, seem to be generally higher than expected from the $\delta^{18} \mathrm{O}$ values of the rainfall. We note, however, that the rainfall $\delta^{18} \mathrm{O}$ data are associated with considerable uncertainty. Firstly, $\delta^{18} \mathrm{O}$ values for some winter months are missing because the cave site is difficult to access during winter. These values have been replaced by the mean values of the previous/subsequent years in order to minimise the resulting bias. Secondly, the absolute $\delta^{18} \mathrm{O}$ values of the rainfall at Lavarone and Grotta di Ernesto may be significantly different due to local orographic effects (Fig. 1). This is confirmed by the comparison of the monthly $\delta^{18} \mathrm{O}$ values of the rainfall at Lavarone and Grotta di Ernesto, which have been measured since 2006. Whereas the general trend is similar for both sites, the absolute values differ by up to $7 \%$. Between 2006 and 2008 the mean $\delta^{18} \mathrm{O}$ value at Grotta di Ernesto is higher by $0.6 \%$. Unfortunately, monthly rainfall amounts are not available for the cave site.

The observation that the $\delta^{18} \mathrm{O}$ values of the drip water are higher than expected from the rainfall data may be explained by several processes: (i) evaporation in the soil zone, (ii) refreezing of melting snow, or (iii) a lower contribution of the winter precipitation than suggested by our calculations. The first process is related to soil temperature and should, thus, be largest during summer months. However, in the observation period between 2004 and 2007, potential evapo-transpiration in summer was much higher than the monthly amount of precipitation. Thus, summer precipitation should not have significantly contributed to the recharge water and evaporation in the soil zone is unlikely to have had a significant influence at Grotta di Ernesto. The second process was observed for melting and refreezing of a thick snow cover in Japan (Zhou et al., 2008). Even if most of the winter precipitation falling at Grotta di Ernesto is snow, a substantial part of the snowfall does not reach the ground due to the shielding effect of the canopy. Refreezing of melt water is, thus, not expected to have a significant effect on the $\delta^{18} \mathrm{O}$ values of the cave drip water. The third process, in contrast, may have a substantial effect. A significant proportion of the winter precipitation falling as snow is probably sublimated from the canopy, blown away or slides downhill along the steep slope above the cave. Thus, it should not contribute to the infiltrating water. These processes are not accounted for in our calculations and would lead to a lower contribution of winter precipitation and, thus, to a higher $\delta^{18} \mathrm{O}$ value of the drip water.

The effect of reduced contribution of winter precipitation is likely to be most pronounced in dry winters. We have shown an influence of the NAO on winter precipitation amount in the study region (Sect. 3.1). It is, thus, possible that during $\mathrm{NAO}^{+}$phases, which are associated with dry winters, the $\delta^{18} \mathrm{O}$ values of the cave drip water are biased towards higher values. During $\mathrm{NAO}^{-}$phases, associated with higher winter precipitation, one would expect lower $\delta^{18} \mathrm{O}$ values. Unfortunately, our cave monitoring dataset is too short to test this hypothesis.

In summary, the interpretation of the $\delta^{18} \mathrm{O}$ signal recorded in ER 76 is complex due to the potential influence of several competing mechanisms. The comparison with meteorological data suggests only a small contribution of summer rainfall to the recharge water. In addition, a significant amount of winter precipitation, deposited as snow, seems not to contribute to the drip water budget.

\subsubsection{Dead carbon fraction}

The dcf is a measure of the proportion of carbon derived from limestone dissolution and degradation of old soil organic matter (Genty et al., 1999). Two end-member models were proposed describing the processes by which percolating groundwater dissolves calcium carbonate in the soil and the host rock above a cave, i.e., an open- and a closed-system model (Fohlmeister et al., 2011b; Hendy, 1971). Whereas increasing soil $p \mathrm{CO}_{2}$ should generally result in lower dcf values in a closed system, the same scenario produces higher dcf values in an open system (Fohlmeister et al., 2011b). For a partially open system, there is no longer a clear relationship between dcf and soil $p \mathrm{CO}_{2}$ (Fohlmeister et al., 2011b), and most natural systems are likely to be partially 
open (McDermott, 2004). Given the range of soil $p \mathrm{CO}_{2}$ values measured at Grotta di Ernesto, which vary from 1500 to 10000 ppmv within a year, we expect increasing dcf with increasing soil $p \mathrm{CO}_{2}$ for a partially open system. Thus, the increasing dcf values observed in ER 76 within the Late Holocene (Fig. 3) support our assumption of progressive development of an increasingly mature and thicker soil profile during the past $8 \mathrm{ka}$ and increasing admixture of "old" carbon derived from the degradation of older plant components.

\subsection{Climate variability in north-eastern Italy between 8.2 and $2.6 \mathrm{ka}$ and the potential influence of the NAO}

Figure 7 shows a comparison of the lamina thickness and stable isotope records of ER 76 with other stalagmite $\delta^{18} \mathrm{O}$ records. On the basis of relatively high values of lamina thickness (i.e., $>100 \mu \mathrm{m}$ ), we identify six periods of warm winter climate in the region of Grotta di Ernesto. These are centred at 7.9, 7.4, 6.5, 5.5, 4.9 and $3.7 \mathrm{ka}$, respectively, and their duration ranges from 100 to $400 \mathrm{a}$ (Fig. 7). In addition, a few short-term episodes are observed in the uppermost section of ER 76 (Fig. 7).

During five of these phases, the $\delta^{13} \mathrm{C}$ record of ER 76 shows negative peaks or a clear trend to more negative values (Fig. 7). The exception is the period at $4.9 \mathrm{ka}$, which exhibits a trend to more positive values. This suggests less influence of rapid degassing on $\delta^{13} \mathrm{C}$ values due to mild winters and/or a rapid development of the soil profile in response to warm climate and supports our interpretation of the lamina thickness record. The period around $4.9 \mathrm{ka}$ shows increasing instead of decreasing $\delta^{13} \mathrm{C}$ values and, thus, represents an exception in this context (Fig. 7).

The $\delta^{18} \mathrm{O}$ record of stalagmite ER 76 shows both high and low values during these warm phases. During the two oldest warm periods (i.e., around 7.9 and $7.4 \mathrm{ka}$ ), the ER 76 record exhibits the highest average $\delta^{18} \mathrm{O}$ values of the whole record (Fig. 7), which has been interpreted as reflecting increased advection of Mediterranean moisture towards the Alps (Spötl et al., 2010). During the other warm periods, however, the $\delta^{18} \mathrm{O}$ record shows substantial variability, in particular, between 5.6 and $5.4 \mathrm{ka}$ (Fig. 7). This confirms our previous conclusion that the $\delta^{18} \mathrm{O}$ signal recorded at Grotta di Ernesto is difficult to interpret and is potentially influenced by surface temperature, the $\delta^{18} \mathrm{O}$ value of local precipitation as well as other surface and cave processes (compare Sect. 4.1.4).

The other $\delta^{18} \mathrm{O}$ records shown in Fig. 7 are arranged from top down according to their geographic location (Fig. 1), with the northernmost record plotted at the top. The COMNISPA $\delta^{18} \mathrm{O}$ record (Vollweiler et al., 2006) is a composite record of three stalagmites from Spannagel cave, Austrian Alps (Fig. 1). COMNISPA shows a very good agreement with changes in ice-rafted debris recorded in North Atlantic sediments (Mangini et al., 2007), which are a proxy for the proportion of ice-bearing surface water from north of Iceland

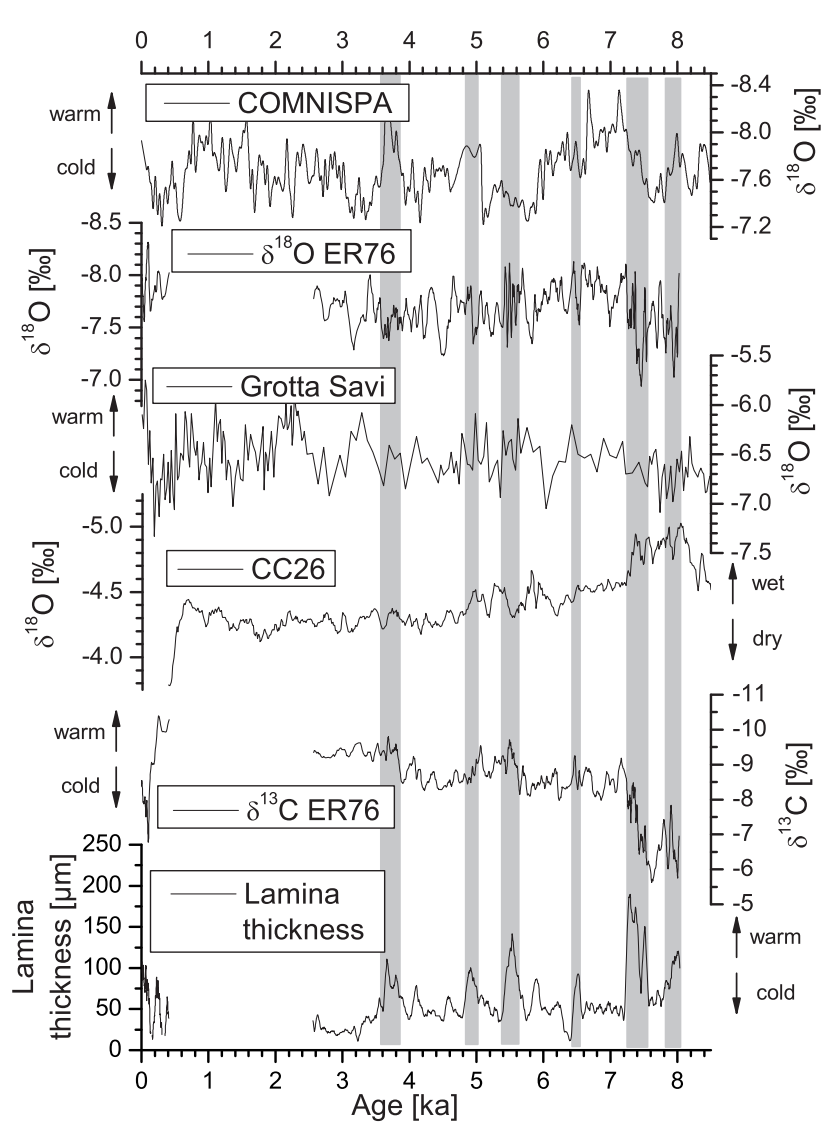

Fig. 7. Comparison of the stable isotope and lamina thickness records of ER 76 with the $\delta^{18} \mathrm{O}$ record of stalagmite CC26 from Corchia cave (central Italy, Zanchetta et al., 2007), the $\delta^{18} \mathrm{O}$ record of stalagmite SV1 from Grotta Savi (northern Italy, Frisia et al., 2005) and a speleothem $\delta^{18} \mathrm{O}$ record from the Austrian Alps (COMNISPA, Vollweiler et al., 2006). All records are dated by U-series methods, and each record is plotted on its own time scale. Note that the y-axis scales of all stable isotope records except for that of stalagmite SV1 are inverted. Arrows next to the individual records indicate the relationship between the corresponding proxy and climate. Phases of warm winter climate at Grotta di Ernesto, as indicated by positive peaks in lamina thickness and negative peaks in $\delta^{13} \mathrm{C}$, are highlighted in light grey.

(Bond et al., 2001). COMNISPA is, thus, interpreted as reflecting Holocene climate variability in the North Atlantic and central Europe, with lower $\delta^{18} \mathrm{O}$ values corresponding to warmer and/or wetter climate (Fig. 7). A recent study also demonstrated a very good agreement between COMNISPA and an NAO reconstruction for the last 900 a (Trouet et al., 2009). The $\delta^{18} \mathrm{O}$ record from stalagmite SV1 (Frisia et al., 2005) from Grotta Savi, located at the south-eastern margin of the European Alps (Fig. 1), reflects long-term changes in past temperature variability as has been demonstrated by calibration with historical data. Finally, the $\delta^{18} \mathrm{O}$ record of stalagmite CC26 from Corchia cave (Alpi Apuane, centralwestern Italy, Fig. 1) has been interpreted to reflect rainfall of 
both North Atlantic and Mediterranean origin, with intervals of lower $\delta^{18} \mathrm{O}$ values corresponding to enhanced rainfall and warmer sea-surface temperatures (Zanchetta et al., 2007). A recent compilation of Holocene speleothem $\delta^{18} \mathrm{O}$ data from Europe clearly documents the influence of Mediterranean source water at Corchia cave (McDermott et al., 2011). Particularly low $\delta^{18} \mathrm{O}$ values recorded in $\mathrm{CC} 26$ during the time of the formation of sapropel S1 in the Mediterranean Sea provide evidence for enhanced rainfall in the western Mediterranean basin (Zanchetta et al., 2007).

The $\delta^{18} \mathrm{O}$ record of ER 76 does not show a strong similarity with any of the other $\delta^{18} \mathrm{O}$ records during the Holocene (Fig. 7). It is obvious, however, that the general trend of the $\delta^{18} \mathrm{O}$ records of the two stalagmites from north-eastern Italy (i.e., ER 76 and SV1) is very different from that of stalagmite $\mathrm{CC} 26$, which shows a clear trend to higher $\delta^{18} \mathrm{O}$ values after $\sim 7 \mathrm{ka}$. In contrast, the general trend of the $\delta^{18} \mathrm{O}$ records of ER 76 and SV1 is more similar to COMNISPA, which reflects North Atlantic/central European climate variability. This suggests an influence from northern trajectories during the majority of the Holocene and a different climate evolution in north-eastern than in central-western Italy.

The warm climate conditions during the oldest two warm phases recorded in ER 76 (i.e., around 7.9 and $7.4 \mathrm{ka}$ ) are also recorded by other proxy data from the cave region, such as pollen from Lavarone (Frisia et al., 2007) and the occurrence of thick calcareous tufa deposits in mid-altitude caves in Trentino (Borsato et al., 2007b). These two warm phases coincide with the period of maximum rainfall recorded in stalagmite CC26 in the Holocene (8.9-7.3 ka, Fig. 7, Zanchetta et al., 2007) during the deposition of sapropel S1 in the Mediterranean Sea (Emeis et al., 2000). Interestingly, relatively low lamina thickness values in ER 76 between 7.8 and $7.6 \mathrm{ka}$ (Fig. 7) indicate a period of lower temperatures. While there is no equivalent in the $\delta^{18} \mathrm{O}$ signal of CC26, several Mediterranean records indicate an interruption of sapropel deposition between 8.0 and $7.5 \mathrm{ka}$ (Bar-Matthews et al., 2000 ), even if the timing and duration of this event is controversial (Ariztegui et al., 2000; Zhornyak et al., 2011). The $\delta^{18} \mathrm{O}$ values of ER 76 during these two warm phases are the highest of the whole record (Fig. 7). Since precipitation of Mediterranean origin has higher $\delta^{18} \mathrm{O}$ values than rainfall from the North Atlantic region (Celle-Jeanton et al., 2004), this may indicate a stronger influence of Mediterranean climate in the region of Grotta di Ernesto during deposition of sapropel S1 (Spötl et al., 2010). The $\delta^{18} \mathrm{O}$ record from Grotta Savi, in contrast, shows no strong excursion during the sapropel phase (Fig. 7) suggesting that the wet phase in the Mediterranean area was not accompanied by strong temperature variability in the south-eastern Alps. The COMNISPA record exhibits relatively high $\delta^{18} \mathrm{O}$ values during the sapropel phase (Fig. 7) indicating cool climate in central Europe. In summary, the comparison of the four stalagmite records indicates that the extraordinary climate conditions in the Mediterranean area during the deposition of sapropel S1 were clearly visible in central-western Italy (i.e., in the $\mathrm{CC} 26$ record) and the region of Grotta di Ernesto but less influential at the other cave sites.

For the subsequent warm phases identified in the lamina thickness record, it is difficult to establish similar patterns. For example, neither the COMNISPA nor the CC26 record shows extraordinary isotope excursions during the warm phase around $6.5 \mathrm{ka}$ (Fig. 7). High $\delta^{18} \mathrm{O}$ values recorded in SV1 suggest a local warm phase in north-eastern Italy. Around $5.5 \mathrm{ka}$, climate in central Europe was rather cold according to the high $\delta^{18} \mathrm{O}$ values of COMNISPA, and the CC26 record shows a considerable negative peak around that time (Fig. 7). This indicates warm and wet climate conditions in central-western Italy, which were also visible in the region of Grotta di Ernesto. $\delta^{18} \mathrm{O}$ values of SV1 do not show much change during this period (Fig. 7). During the warm phases around 4.9 and $3.7 \mathrm{ka}$, in turn, COMNISPA exhibits distinct minima indicating warm climate in central Europe (Fig. 7). The CC26 record shows a small negative peak around $5.0 \mathrm{ka}$, but normal values around $3.7 \mathrm{ka}$ (Fig. 7). This suggests that climatic conditions at Grotta di Ernesto during these phases were similar to the conditions in central Europe. A dry event around $4 \mathrm{ka}$, which is clearly reflected in the proxy data of a flowstone from Buca della Renella (Alpi Apuane, centralwestern Italy, Drysdale et al., 2006), is also not visible in the ER 76 data. In contrast, low values of lamina thickness and high $\delta^{13} \mathrm{C}$ values in ER 76 suggest cool climate at Grotta di Ernesto at $4.2 \mathrm{ka}$ as well as in central Europe as reflected by high $\delta^{18} \mathrm{O}$ values in COMNISPA (Fig. 7). This confirms the complexity of this dry episode, which is observed in tropical areas as well as in northwestern Italy (Magny et al., 2009). In summary, it is not possible to establish a clear, supra-regional climate pattern for the warm phases recorded in stalagmite ER 76. This may either be related to the general complexity of Holocene climate variability in Europe (Wanner et al., $2008,2011)$ or to local orographic effects.

In the first case, the cave area seems to have been influenced by both northern and southern climate variability during the Holocene, which may be related to its key position between central Europe and the Mediterranean. The high lamina thickness and $\delta^{18} \mathrm{O}$ values and the large decrease in $\delta^{13} \mathrm{C}$ during the sapropel phase suggest a strong impact of this pluvial phase in north-eastern Italy. However, the other warm phases do not have such clear counterparts in the CC26 $\delta^{18} \mathrm{O}$ record. In contrast, the phases around 4.9 and $3.7 \mathrm{ka}$, respectively, coincide with distinct warm phases recorded in the COMNISPA record and may, thus, have been triggered from the North Atlantic.

The variability of the NAO has a contrasting influence on the climatic conditions in central Europe and the Mediterranean area since the Azorean high and Icelandic low pressure cells direct the atmospheric flow either eastward into the Mediterranean area or north-eastward to northern Europe according to their positions. There are several indications that the NAO plays a major role for winter climate 
in the cave region: (i) the comparison of the winter NAO index and winter temperature and precipitation in Trentino shows that winter climate in the cave area is influenced by the NAO (Sect. 3.1). (ii) spectral analysis of the stable isotope signals of ER 76 suggests an influence of the NAO and solar variability during the Holocene (Fig. 4). (iii) spectral analysis of the lamina thickness record for the last $\sim 500 \mathrm{a}$ indicates an influence of the NAO on winter temperature at Grotta di Ernesto (Frisia et al., 2003). Today, positive phases of the NAO are associated with warmer and drier than normal winters in northern Italy, weakening of the Mediterranean cyclones and a northward shift of the storm tracks. In contrast, negative phases of the NAO are characterised by colder winters, higher precipitation and stronger westerly winds (Efthymiadis et al., 2007). Phases of different intensity of the NAO may be reflected in the $\delta^{18} \mathrm{O}$ signal of ER 76 due to variable contribution of winter precipitation to the recharge water as well as in the lamina thickness profile and $\delta^{13} \mathrm{C}$ values, which are a proxy for winter temperature and duration (Frisia et al., 2003, 2011). The NAO, thus, probably influenced both winter temperature and precipitation at Grotta di Ernesto. However, since the $\delta^{18} \mathrm{O}$ signal probably reflects a combination of temperature and precipitation variability, it is not possible to quantify and reconstruct the potential influence of the NAO on winter climate at the cave site. Nevertheless, the six warm phases observed in the ER 76 record may be interpreted as persistent positive phases of the NAO. In this case, one would expect warm climate conditions in central Europe (i.e., positive $\delta^{18} \mathrm{O}$ values in the COMNISPA record) and drier conditions in the Mediterranean area (i.e., positive $\delta^{18} \mathrm{O}$ values in the $\mathrm{CC} 26$ record). However, the observed patterns are not consistent in this context. Thus, it is likely that some of the warm phases identified in stalagmite ER 76 rather reflect regional or local climate phenomena and are not related to past NAO variability.

\section{Conclusions}

Several climate-sensitive proxies, whose interpretation is based on a long-term cave monitoring programme, were measured at high resolution in stalagmite ER 76. High lamina thickness and low $\delta^{13} \mathrm{C}$ values reflect warm winter temperatures. Millennial-scale changes in $\delta^{13} \mathrm{C}$ values and textures reflect the progressive evolution of the soil profile, which is confirmed by the progressive increase in the dcf. The $\delta^{18} \mathrm{O}$ signal seems to be influenced by a complex interplay of several climate parameters and is, despite of the wealth of the monitoring data, difficult to interpret. Thus, the most robust proxies for past climate variability recorded in speleothems at Grotta di Ernesto are $\delta^{13} \mathrm{C}$ values and lamina thickness.

Comparison of winter climate data since 1921 from meteorological stations in the cave area with the winter NAO index reveals a significant influence of the NAO on winter climate, with warmer and drier conditions corresponding to
$\mathrm{NAO}^{+}$conditions. Spectral analysis of the stable isotope signals of ER 76 shows significant peaks at 110, 60-70, 40-50, 32-37 and around $25 \mathrm{a}$. The 25-a cycle may correspond to NAO variability. Except for the cycle between 32 and 37 a all periodicities have corresponding peaks in power spectra of solar variability (Ogurtsov et al., 2002; Peristykh and Damon, 2003) suggesting an influence of both solar activity and the NAO on Holocene climate in northern Italy.

On the basis of high lamina thickness and low $\delta^{13} \mathrm{C}$ values, six periods of warm winter climate in the cave region were identified. These are centred at 7.9, 7.4, 6.5, 5.5, 4.9 and $3.7 \mathrm{ka}$, respectively, and their duration ranges from 100 to $400 \mathrm{a}$. The two oldest warm phases coincide with the deposition of sapropel S1, suggesting that climate in the cave region was influenced by this prominent pluvial phase in the Mediterranean area. For the younger warm phases, it is difficult to establish a general supra-regional climate pattern, and some of them may, thus, rather reflect regional climate variability.

The comparison with the other stalagmite $\delta^{18} \mathrm{O}$ records confirms the complexity of regional and supra-regional scale Holocene climate patterns also identified in other studies (Davis et al., 2003; Magny et al., 2003, 2006; Drysdale et al., 2006; Wanner et al., 2008, 2011). In particular, the cave site seems to have been influenced by both northern and southern climate variability during the Holocene, which may have been related to past variability of the NAO. The diversity of the different speleothem $\delta^{18} \mathrm{O}$ records, however, also highlights the influence of regional orographic effects.

Acknowledgements. We are thankful to Giovanni Zanchetta and an anonymous reviewer for their constructive and thorough reviews. We also thank Russell Drysdale for providing the stable isotope record of stalagmite CC26. D. Scholz, S. Frisia, J. Fohlmeister, M. Mudelsee and R. Miorandi are grateful to the DFG Research Group 668 (DAPHNE) for financial support. C. Spötl acknowledges long-term support from FWF.

Edited by: D. Fleitmann

\section{References}

Ariztegui, D., Asioli, A., Lowe, J. J., Trincardi, F., Vigliotti, L., Tamburini, F., Chondrogianni, C., Accorsi, C. A., Bandini Mazzanti, M., Mercuri, A. M., Van der Kaars, J. A., and Oldfield, F.: Paleoclimate and the formation of sapropel S1: inferences from Late Quaternary lacustrine and marine sequences in the central Mediterranean region, Palaeogeogr. Palaeocl., 158, 215240, 2000.

Bar-Matthews, M., Ayalon, A., and Kaufman, A.: Timing and hydrological conditions of Sapropel events in the Eastern Mediterranean, as evident from speleothems, Soreq cave, Israel, Chem. Geol., 169, 145-156, 2000.

Baroni, C., Bruschi, G., Veronese, L., and Zanchetta, G.: Younger Dryas to Early Holocene paleoenvironmental evolution of the 
Lake Terlago (southern Alps), Geogr. Fis. Din. Quat., 24, 13-24, 2001.

Baroni, C., Zanchetta, G., Fallick, A. E., and Longinelli, A.: Mollusca stable isotope record of a core from Lake Frassino, northern Italy: hydrological and climatic changes during the last $14 \mathrm{ka}$, Holocene, 16, 827-837, 2006.

Bertò, A., Buzzi, A., and Zardi, D.: Back-tracking water vapour contributing to a precipitation event over Trentino: a case study, Meteorol. Z., 13, 189-200, 2004.

Bond, G., Kromer, B., Beer, J., Muscheler, R., Evans, M. N., Showers, W., Hoffmann, S., Lotti-Bond, R., Hajdas, I., and Bonani, G.: Persistent solar influence on North Atlantic climate during the Holocene, Science, 294, 2130-2136, 2001.

Borsato, A., Frisia, S., Fairchild, I. J., Somogyi, A., and Susini, J.: Trace element distribution in annual stalagmite laminae mapped by micrometer-resolution X-ray fluoresence: implications for incorporation of environmentally significant species, Geochim. Cosmochim. Ac., 71, 1494-1512, 2007a.

Borsato, A., Frisia, S., Miorandi, R., van der Borg, K., Spötl, C., and Corradini, F.: Holocene climate and environmental reconstruction from calcareous tufa and moonmilk deposits in Trentino caves, Acta Geol., 83, 239-260, 2007b.

Celle-Jeanton, H., Travi, Y., and Blavoux, B.: Isotopic typology of the precipitation in the Western Mediterranean region at three different time scales, Geophys. Res. Lett., 28, 1215-1218, 2004.

Cerling, T. E.: The stable isotopic composition of modern soil carbonate and its relationship to climate, Earth Planet. Sc. Lett., 71, 229-240, 1984

Cheng, H., Edwards, R. L., Hoff, J., Gallup, C. D., Richards, D. A., and Asmerom, Y.: The half-lives of uranium-234 and thorium230, Chem. Geol., 169, 17-33, 2000.

Cook, E. R., D'Arrigo, R., and Briffa, K. R.: A reconstruction of the North Atlantic Oscillation using tree-ring chronologies from North America and Europe, Holocene, 8, 9-17, 1998.

Davis, B. A. S., Brewer, S., Stevenson, A. C., and Guiot, J.: The temperature of Europe during the Holocene reconstructed from pollen data, Quaternary Sci. Rev., 22, 1701-1716, 2003.

Dorale, J. A. and Liu, Z.: Limitations of Hendy test criteria in judging the paleoclimatic suitability of speleothems and the need for replication, J. Cave Karst Stud., 71, 73-80, 2009.

Dreybrodt, W. and Scholz, D.: Climatic dependence of stable carbon and oxygen isotope signals recorded in speleothems: From soil water to speleothem calcite, Geochim. Cosmochim. Ac., 75, 734-752, 2011.

Drysdale, R. N., Zanchetta, G., Hellstrom, J. C., Maas, R., Fallick, A. E., Pickett, M., Cartwright, I., and Piccini, L.: Late Holocene drought responsible for the collapse of the Old World civilizations is recorded in an Italian cave flowstone, Geology, 34, 101104, 2006

Efthymiadis, D., Jones, P. D., Briffa, K. R., Böhm, R., and Maugeri, M.: Influence of large-scale atmospheric circulation on climate variability in the Greater Alpine Region of Europe, J. Geophys. Res., 112, D12104, doi:10.1029/2006JD008021, 2007.

Emeis, K.-C., Struck, U., Schulz, H.-M., Rosenberg, R., Bernasconi, S., Erlenkeuser, H., Sakamoto, T., and MartinezRuiz, F.: Temperature and salinity variations of Mediterranean Sea surface waters over the last 16,000 years from records of planktonic stable oxygen isotope and alkenone unsaturation ratios, Palaeogeogr. Palaeocl., 158, 259-280, 2000.
Fairchild, I. J., Frisia, S., Borsato, A., and Tooth, A. F.: Speleothems, in: Geochemical Sediments and Landscapes, edited by: Nash, D. J. and McLaren, S. J., Blackwells, Oxford, 200-246, 2007.

Filippi, M. L., Heiri, O., Arpenti, E., Angeli, N., Bortolottio, M., Lotter, A. F., and van der Borg, K.: Paleoenvironmental evolution from Lateglacial to present as reconstructed from Lago di Lavarone sediment sequence (Folgaria and Lavarone Plateau, Trentino), Acta Geol., 82, 279-298, 2007.

Fohlmeister, J., Kromer, B., and Mangini, A.: The influence of soil organic matter age spectrum on the reconstruction of atmospheric ${ }^{14} \mathrm{C}$ levels via stalagmites, Radiocarbon, 53, 99-115, 2011a.

Fohlmeister, J., Scholz, D., Kromer, B., and Mangini, A.: Modelling carbon isotopes of carbonates in cave drip water, Geochim. Cosmochim. Ac., 75, 5219-5228, 2011 b.

Frisia, S. and Borsato, A.: Karst, in: Carbonates in Continental Settings, edited by: Alonso-Zarza, A. M. and Tanner, L. H., Developments in Sedimentology, Elsevier, Amsterdam, 269-318, 2010.

Frisia, S., Borsato, A., Fairchild, I. J., and McDermott, F.: Calcite fabrics, growth mechanisms, and environments of formation in speleothems from the Italian Alps and South-western Ireland, J Sediment. Res., 70, 1183-1196, 2000.

Frisia, S., Borsato, A., Preto, N., and McDermott, F.: Late Holocene annual growth in three Alpine stalagmites records the influence of solar activity an the North Atlantic Oscillation on winter climate, Earth Planet. Sc. Lett., 216, 411-424, 2003.

Frisia, S., Borsato, A., Spötl, C., Villa, I., and Cucchi, F.: Climate variability in the SE Alps of Italy over the past 17000 years reconstructed from a stalagmite record, Boreas, 34, 445-455, 2005.

Frisia, S., Borsato, A., Mangini, A., Spötl, C., Madonia, G., and Sauro, U.: Holocene climate variability in Sicily from a discontinuous stalagmite record and the Mesolithic to Neolithic transition, Quaternary Res., 66, 388-400, 2006.

Frisia, S., Filippi, M. L., and Borsato, A.: Paleoclimate and paleoenvironmental evolution for the Lateglacial and Holocene in Trentino: a synthesis from the AQUAPAST and OLOAMBIENT projects, Acta Geol., 82, 325-330, 2007.

Frisia, S., Fairchild, I. J., Fohlmeister, J., Miorandi, R., Spötl, C., and Borsato, A.: Carbon mass-balance modelling and carbon isotope exchange processes in dynamic caves, Geochim. Cosmochim. Ac., 75, 380-400, 2011.

Genty, D., Massault, M., Gilmour, M., Baker, A., Verheyden, S., and Keppens, E.: Calculation of past dead carbon proportion and variability by the comparison of AMS ${ }^{14} \mathrm{C}$ and TIMS U/Th ages on two Holocene stalagmites, Radiocarbon, 41, 251-270, 1999.

Heegaard, E., Birks, H. J. B., and Telford, R. J.: Relationships between calibrated ages and depth in stratigraphical sequences: an estimation procedure by mixed-effect regression, Holocene, 15, 612-618, 2005.

Hendy, C. H.: The isotopic geochemistry of speleothems - I. The calculation of the effects of different modes of formation on the isotopic composition of speleothems and their applicability as paleoclimatic indicators, Geochim. Cosmochim. Ac., 35, 801824, 1971.

Hoffmann, D. L., Prytulak, J., Richards, D. A., Elliott, T., Coath, C. D., Smart, P. L., and Scholz, D.: Procedures for accurate U and Th isotope measurements by high precision MC-ICPMS, Int. J. 
Mass Spectrom., 264, 97-109, 2007.

Holzhauser, H., Magny, M., and Zumbühl, H. J.: Glacier and lakelevel variations in west-central Europe over the last 3500 years, Holocene, 15, 789-801, 2005.

Huang, Y., Fairchild, I. J., Borsato, A., Frisia, S., Cassidy, N. J., McDermott, F., and Hawkesworth, C. J.: Seasonal variations in $\mathrm{Sr}, \mathrm{Mg}$ and $\mathrm{P}$ in modern speleothems (Grotta di Ernesto, Italy), Chem. Geol., 175, 429-448, 2001.

Hurrell, J. W.: Decadal trends in the North Atlantic Oscillation: Regional temperatures and precipitation, Science, 269, 676-679, doi:10.1126/science.269.5224.676, 1995.

Joerin, U. E., Stocker, T. F., and Schlüchter, C.: Multicentury glacier fluctuations in the Swiss Alps during the Holocene, Holocene, 16, 697-704, 2006.

Kim, S.-T. and O’Neil, J. R.: Equilibrium and nonequilibrium oxygen isotope effects in synthetic carbonates, Geochim. Cosmochim. Ac., 61, 3461-3475, 1997.

Lachniet, M. S.: Climatic and environmental controls on speleothem oxygen-isotope values, Quaternary Sci. Rev., 28, 412-432, 2009.

Magny, M.: Holocene climate variability as reflected by midEuropean lake-level fluctuations and its probable impact on prehistoric human settlements, Quaternary Int., 113, 65-79, 2004.

Magny, M., Bégeot, C., Guiot, J., and Peyron, O.: Contrasting patterns of hydrological changes in Europe in response to Holocene climate cooling phases, Quaternary Sci. Rev., 22, 1589-1596, 2003

Magny, M., Leuzinger, U., Bortenschlager, S., and Haas, J. N.: Tripartite climate reversal in Central Europe 5600-5300 yr ago, Quaternary Res., 65, 3-19, 2006.

Magny, M., de Beaulieu, J.-L., Drescher-Schneider, R., Vannière, B., Walter-Simonnet, A.-V., Miras, Y., Millet, L., Bossuet, G., Peyron, O., Brugliapaglia, E., and Leroux, A.: Holocene climate changes in the central Mediterranean as recorded by lake-level fluctuations at Lake Accesa (Tuscany, Italy), Quaternary Sci. Rev., 26, 1736-1758, 2007.

Magny, M., Vannière, B., Zanchetta, G., Fouache, E., Touchais, G., Petrika, L., Coussot, C., Walter-Simonnet, A.-V., and Arnaud, F.: Possible complexity of the climatic event around 4300 $3800 \mathrm{cal}$. BP in the central and western Mediterranean, Holocene, 19, 823-833, doi:10.1177/0959683609337360, 2009.

Mangini, A., Spötl, C., and Verdes, P.: Reconstruction of temperature in the Central Alps during the past $2000 \mathrm{yr}$ from a $\delta^{18} \mathrm{O}$ stalagmite record, Earth Planet. Sc. Lett., 235, 741-751, 2005.

Mangini, A., Verdes, P., Spötl, C., Scholz, D., Vollweiler, N., and Kromer, B.: Persistent influence of the North Atlantic hydrography on central European winter temperature during the last 9000 years, Geophys. Res. Lett., 34, L02704, doi:10.1029/2006GL028600, 2007.

Mayewski, P. A., Rohling, E. J., Stager, J. C., Karlén, W., Maasch, K. A., Meeker, L. D., Meyerson, E. A., Gasse, F., van Kreveld, S., Holmgren, K., Lee-Thorp, J., Rosqvist, G., Rack, F., Staubwasser, M., Schneider, R. R., and Steig, E. J.: Holocene climate variability, Quaternary Res., 62, 243-255, 2004.

McDermott, F.: Palaeo-climate reconstruction from stable isotope variations in speleothems: a review, Quaternary Sci. Rev., 23, 901-918, 2004.

McDermott, F., Frisia, S., Huang, Y., Longinelli, A., Spiro, B., Heaton, T. H. E., Hawkesworth, C. J., Borsato, A., Keppens, E.,
Fairchild, I. J., van der Borg, K., Verheyden, S., and Selmo, E. M.: Holocene climate variability in Europe: Evidence from $\delta^{18} \mathrm{O}$, textural and extension-rate variations in three speleothems, Quaternary Sci. Rev., 18, 1021-1038, 1999.

McDermott, F., Atkinson, T. C., Fairchild, I. J., Baldini, L. M., and Mattey, D. P.: A first evaluation of the spatial gradients in $\delta^{18} \mathrm{O}$ recorded by European Holocene speleothems, Global Plane. Change, 79, 275-287, 2011.

Meyer, M. C., Faber, R., and Spötl, C.: The WinGeol Lamination Tool: new software for rapid, semi-automated analysis of laminated climate archives, Holocene, 16, 753-761, doi:10.1191/0959683606hl969rr, 2006.

Mickler, P. J., Stern, L. A., and Banner, J. L.: Large kinetic isotope effects in modern speleothems, Geol. Soc. Am. Bull., 118, 6581, 2006.

Miorandi, R., Borsato, A., Frisia, S., Fairchild, I. J., and Richter, D. K.: Epikarst hydrology and implications for stalagmite capture of climate changes at Grotta di Ernesto (NE Italy): results from long-term monitoring, Hydrol. Process., 24, 3101-3114, 2010.

Mudelsee, M.: Estimating Pearson's correlation coefficient with bootstrap confidence interval from serially dependent time series, Math. Geol., 35, 651-665, 2003.

Mühlinghaus, C., Scholz, D., and Mangini, A.: Modelling fractionation of stable isotopes in stalagmites, Geochim. Cosmochim. Ac., 73, 7275-7289, 2009.

Nicolussi, K. and Patzelt, G.: Discovery of early-Holocene wood and peat on the forefield of the Pasterze Glacier, Eastern Alps, Austria, Holocene, 10, 191-199, 2000.

North Greenland Ice Core Project members: High-resolution record of Northern Hemisphere climate extending into the last interglacial period, Nature, 431, 147-151, 2004

Ogurtsov, M. G., Nagovitsyn, Y. A., Kocharov, G. E., and Jungner, H.: Long-period cycles of the Sun's activity recorded in direct solar data and proxies, Sol. Phys., 211, 371-394, 2002.

Peristykh, A. N. and Damon, P. E.: Persistence of the Gleissberg 88year solar cycle over the last $\sim 12,000$ years: Evidence from cosmogenic isotopes, J. Geophys. Res. (Space Physics), 108, 1003, doi:10.1029/2002JA009390, 2003.

Rea, R., Zardi, D., and Rampanelli, G.: Analisi di serie storiche di temperatura, in: Analisi climatologica di serie storiche delle precipitazioni e temperature in Trentino, edited by: Bellin, A. and Zardi, D., Quaderni di Idronomia Montana, 23, 135-214, 2004.

Reimer, P. J., Baillie, M. G. L., Bard, E., Bayliss, A., Beck, J. W., Bertrand, C. J. H., Blackwell, P. G., Buck, C. E., Burr, G. S., Cutler, K. B., Damon, P. E., Edwards, R. L., Fairbanks, R. G., Friedrich, M., Guilderson, T. P., Hogg, A. G., Hughen, K. A., Kromer, B., McCormac, G., Manning, S., Ramsey, C. B., Reimer, R. W., Remmele, S., Southon, J. R., Stuiver, M., Talamo, S., Taylor, F. W., van der Plicht, J., and Weyhenmeyer, C. E.: IntCal04 Terrestrial Radiocarbon Age Calibration, 0-26 cal kyr BP, Radiocarbon, 46, 1029-1058, 2004.

Roberts, N., Jones, M. D., Benkaddour, A., Eastwood, W. J., Filippi, M. L., Frogley, M. R., Lamb, H. F., Leng, M. J., Reed, J. M., Stein, M., Stevens, L., Valero-Garcés, B., and Zanchetta, G.: Stable isotope records of Late Quaternary climate and hydrology from Mediterranean lakes: the ISOMED synthesis, Quaternary Sci. Rev., 27, 2426-2441, 2008.

Romanek, C. S., Grossmann, E. L., and Morse, J. W.: Carbon isotopic fractionation in synthetic aragonite and calcite: Effects of 
temperature and precipitation rate, Geochim. Cosmochim. Ac., 56, 419-430, 1992.

Sadler, F. and Bellin, A.: Analisi di serie storiche di precipitazione, in: Analisi climatologica di serie storiche delle precipitazioni e temperature in Trentino, edited by: Bellin, A. and Zardi, D., Quaderni di Idronomia Montana, 23, 24-134, 2004.

Scholz, D., Mangini, A., and Felis, T.: U-series dating of diagenetically altered fossil reef corals, Earth Planet. Sc. Lett., 218, 163-178, 2004.

Scholz, D., Mühlinghaus, C., and Mangini, A.: Modelling $\delta^{13} \mathrm{C}$ and $\delta^{18} \mathrm{O}$ in the solution layer on stalagmite surfaces, Geochim. Cosmochim. Ac., 73, 2592-2602, 2009.

Schulz, M. and Mudelsee, M.: REDFIT: estimating red-noise spectra directly from unevenly spaced paleoclimatic time series, Comput. Geosci., 28, 421-426, 2002.

Smith, C. L., Baker, A., Fairchild, I. J., Frisia, S., and Borsato, A.: Reconstructing hemispheric-scale climates from multiple stalagmite records, International J. Climatol., 26, 1417-1424, 2006.

Spötl, C.: A robust and fast method of sampling and analysis of $\delta^{13} \mathrm{C}$ of dissolved inorganic carbon in ground waters, Isot. Environ. Healt. S., 41, 217-221, 2005.

Spötl, C. and Mattey, D.: Stable isotope microsampling of speleothems: a comparison of drill, micromill and laser ablation techniques, Chem. Geol., 235, 48-58, 2006.

Spötl, C. and Vennemann, T.: Continuous-flow IRMS analysis of carbonate minerals, Rapid Commun. Mass Spectrom., 17, 10041006, 2003.

Spötl, C., Nicolussi, K., Patzelt, G., Boch, R., and Daphne team: Humid climate during deposition of sapropel 1 in the Mediterranean Sea: Assessing the influence of the Alps, Global Planet. Change, 71, 242-248, 2010.

Thornthwaite, C. W.: An approach toward a rational classification of climate, Geogr. Rev., 38, 55-94, 1948.

Trouet, V., Esper, J., Graham, N. E., Baker, A., Scourse, J. D., and Frank, D. C.: Persistent positive North Atlantic Oscillation mode dominated the Medieval Climate Anomaly, Science, 324, 78-80, doi:10.1126/science.1166349, 2009.
Vollweiler, N., Scholz, D., Mühlinghaus, C., Mangini, A., and Spötl, C.: A precisely dated climate record for the last $9 \mathrm{kyr}$ from three high alpine stalagmites, Spannagel Cave, Austria, Geophys. Res. Lett., 33, L20703, doi:10.1029/2006GL027662, 2006.

Wackerbarth, A. K., Scholz, D., Fohlmeister, J., and Mangini, A.: Modelling the $\delta^{18} \mathrm{O}$ value of cave drip water and speleothem calcite, Earth Planet. Sc. Lett., 299, 387-397, 2010.

Wanner, H., Brönnimann, S., Casty, C., Gyalistras, D., Luterbacher, J., Schmutz, C., Stephenson, D. B., and Xoplaki, E.: North Atlantic Oscillation - concepts and studies, Surv. Geophys., 22, 321-382, 2001.

Wanner, H., Beer, J., Bütikofer, J., Crowley, T. J., Cubasch, U., Flückiger, J., Goosse, H., Grosjean, M., Joos, F., Kaplan, J. O., Küttel, M., Müller, S. A., Prentice, I. C., Solomina, O., Stocker, T. F., Tarasov, P., Wagner, M., and Widmann, M.: Mid- to Late Holocene climate change: an overview, Quaternary Sci. Rev., 27, 1791-1828, 2008.

Wanner, H., Solomina, O., Grosjean, M., Ritz, S. P., and Jetel, M.: Structure and origin of Holocene cold events, Quaternary Sci. Rev., 30, 3109-3123, 2011.

Zanchetta, G., Drysdale, R. N., Hellstrom, J. C., Fallick, A. E., Isola, I., Gagan, M. K., and Pareschi, M. T.: Enhanced rainfall in the Western Mediterranean during deposition of sapropel S1: stalagmite evidence from Corchia cave (Central Italy), Quaternary Sci. Rev., 26, 279-286, 2007.

Zhornyak, L. V., Zanchetta, G., Drysdale, R. N., Hellstrom, J. C., Isola, I., Regattieri, E., Piccini, L., Baneschi, I., and Couchoud, I.: Stratigraphic evidence for a "pluvial phase" between ca. 8200-7100 ka from Renella cave (Central Italy), Quaternary Sci. Rev., 30, 409-417, 2011.

Zhou, S., Nakawo, M., Hashimoto, S., and Sakai, A.: The effect of refreezing on the isotopic composition of melting snowpack, Hydrol. Process., 22, 873-882, 2008. 